\title{
Is Delaware Losing Its Cases?
}

\author{
John Armour, Bernard Black and Brian Cheffins ${ }^{*}$
}

\begin{abstract}
Delaware's expert courts are seen as an integral part of the state's success in attracting incorporation by public companies. However, the benefit that Delaware companies derive from this expertise depends on whether corporate lawsuits against Delaware companies are brought before the Delaware courts. We report evidence that these suits are increasingly brought outside Delaware. We investigate changes in where suits are brought using four hand-collected datasets capturing different types of suits: class action lawsuits filed in (i) large M\&A and (ii) leveraged buyout transactions over 19942010; (iii) derivative suits alleging option backdating; and (iv) cases against public company directors that generate one or more publicly available opinions between 1995-2009. We find a secular increase in litigation rates for all companies in large M\&A transactions and for Delaware companies in LBO transactions. We also see trends towards (i) suits being filed outside Delaware in both large M\&A and LBO transactions and in cases generating opinions; and (ii) suits being filed both in Delaware and elsewhere in large M\&A transactions. Overall, Delaware courts are losing market share in lawsuits, and Delaware companies are gaining lawsuits, often filed elsewhere. We find some evidence that the timing of specific Delaware court decisions that affect plaintiffs' firms coincide with the movement of cases out of Delaware. Our evidence suggests that serious as well as nuisance cases are leaving Delaware. The trends we report potentially present a challenge to Delaware's competitiveness in the market for incorporations.
\end{abstract}

JEL classification: K22, K41

Keywords: Delaware, shareholder lawsuits, deal litigation, class actions, derivative actions, options backdating, forum shopping, corporate litigation

"Address correspondence to John Armour, University of Oxford, Faculty of Law, St Cross Building, St Cross Road, Oxford OX1 3UL, UK; email: john.armour@law.ox.ac.uk. Armour is Hogan Lovells Professor of Law and Finance, Faculty of Law and Associate Fellow, Saïd Business School, University of Oxford. Black is Nicholas J. Chabraja Professor of Law and Finance at Northwestern University, Law School and Kellogg School of Management, email: bblack@ northwestern.edu. Cheffins is S.J. Berwin Professor of Corporate Law, Faculty of Law, Cambridge University, UK. e-mail: brc21@cam.ac.uk.

We thank Jessica Erickson for providing her derivative suits data; the law firms which provided us with information on option backdating suits; Douglas Campbell, Nathan Chuang, Mitch Fagen, Tim Gerheim, Jonell Goco, Caroline Hunter, Patrick Luff, Stephen McKay, Jose Mendoza, Alex Ruge, Cephas Sekhar, Li Weng and, especially, Ji Min Park, for excellent research assistance, and Columbia Law School, Oxford University, University of Texas Law School, and the Searle Center on Law, Regulation and Economic Growth at Northwestern University for financial support. We thank Keith Bishop, Jill Fisch, Jeff Gordon, Colin Mayer, Tom Noe, Delaware ViceChancellor Travis Laster and three anonymous JELS referees for helpful comments. The paper has benefited from feedback at the American Law and Economics Association (2011 annual meeting), Canadian Law and Economics Association (2010 annual meeting), Conference on Empirical Legal Studies (2010), Harvard Law School, Stanford Law School, University of Illinois Law School, University of Leeds Law School, University of Oxford Saïd Business School, University of San Diego Law School, USD Law Center on Corporate and Securities Law, Vanderbilt Law School Conference on Corporate Law (2010), and Columbia Law School Conference on The Delaware Court of Chancery: Change and Continuity (2011). We are grateful for helpful discussions with various corporate lawyers, including Randall Baron, Peter Carter, Travis Downs, Joel Friedlander, Stuart Grant, William Lafferty, Mark Lebovitch, Roger Magnuson, Joe Metzler, Ted Mirvis, Stephen Radin, Lee Rudy and Bryn Valler. 
"The important ... benefits created by our judiciary's handling of corporate disputes are endangered if our state's compelling public policy interest in deciding these disputes is not recognized"1

\section{INTRODUCTION}

Delaware dominates the competition between states for incorporations of US public companies.

More than four out of five U.S. public companies that incorporate outside their home state choose Delaware, and nearly three-fifths of all U.S. public companies are incorporated there. ${ }^{2}$ Delaware's Chancery Court is thought to be an important factor in Delaware's dominance. ${ }^{3}$ The Delaware chancellors are selected primarily on the basis of their corporate law expertise, and most of their caseload involves corporate matters. ${ }^{4}$ They have full scope to deploy their expertise in cases that come before them because they decide on both facts and law - there are no juries. Delaware-incorporated companies stand to benefit from this expert judging ex post through sound decisions and ex ante through the precedents generated by prior cases. ${ }^{5}$ These benefits are said to be enhanced by Delaware's substantive law avoiding sharp rules in favour of open-ended ex post standards of fiduciary duty, a structure which both capitalizes on the Delaware courts' strengths and is hard to emulate elsewhere. ${ }^{6}$

The value of expert judges, as part of the overall value of Delaware incorporation, hinges on Delaware courts actually hearing disputes in corporate law cases. Until recently, that case flow was taken for granted. It should not have been. Under the "internal affairs" doctrine, the law of the state of incorporation governs corporate law disputes, regardless of where a suit is

1 Vice-Chancellor Strine, In re Topps Shareholders Litigation 924 A. 2d 951, 959 (Del. Ch., 2007).

2 Bebchuk and Hamdani (2002) (tbls. 2 and 5).

3 For a review of this and other factors, see Romano (1993).

4 Thompson and Thomas (2004a).

5 See, e.g., Romano (1985); Klausner (1995). This claim receives support from empirical findings that firms have a propensity to incorporate in states with higher quality judicial systems (Kahan, 2006).

6 Kamar (1998). 
brought. ${ }^{7}$ This ensures that Delaware's substantive rules govern suits under corporate law against Delaware companies. But it does not guarantee that those disputes will be litigated in Delaware. Rather, plaintiffs can sue wherever they can achieve both personal and subject matter jurisdiction. Both of these are available in Delaware, so Delaware is one possible and often convenient forum. But plaintiff lawyers can typically also obtain jurisdiction and thus sue a company's directors and officers in the state courts of its "home state" (where its headquarters are located), and sometimes also in federal courts in the company's home state. Changes in the factors affecting their decisions where to file could affect Delaware's case flow.

In earlier work comparing corporate litigation in the U.S. and the U.K., we reported preliminary evidence that a rising fraction of suits against Delaware companies under Delaware corporate law were being filed outside Delaware. ${ }^{8}$ But we deferred a careful assessment of this possible "out of Delaware" trend to a separate project - this one. Here, we investigate that trend and seek to explain changes over time in the choice of forum for corporate litigation. ${ }^{9}$ To do so, we use four different hand-collected datasets that together capture a broad range of corporate law litigation: (i) lawsuits, mostly class actions, filed in large merger and acquisitions ("M\&A") transactions announced between 1994-2010; (ii) lawsuits, again mostly class actions, filed in leveraged buyout (“LBO”) transactions announced between 1995-2010; (iii) derivative suits alleging option backdating; and (iv) cases - a mix of derivative suits and direct suits, often class actions - against public company directors that generate one or more publicly available written judicial opinions between 1995-2009.

7 See CTS Corporation v Dynamics Corporation of America, 481 U.S. 69, at 89-90 (1987); Tung (2006).

8 Armour, Black, Cheffins and Nolan (2009) (hereinafter, ABCN), fig. 1.

9 Two companion articles develop hypotheses about potential causes of the trend, and assess its policy implications. See Armour, Black and Cheffins (2012) (hereinafter "ABC Balancing Act"); Cheffins, Armour and Black (2012) (hereinafter "CAB Plaintiffs' Bar"). This article focuses on analysis of the data and testing of hypotheses. 
All four datasets present a consistent story: There has been a large decline in the proportion of corporate lawsuits involving Delaware companies (by which we mean shareholder suits against the directors, officers, or controlling shareholders of these companies) filed in Delaware courts. This has been associated with a separate trend toward a higher overall rate of corporate litigation involving large M\&A transactions and LBOs. The trend toward higher litigation rates has affected all public companies, but is especially pronounced for Delaware companies, with the increase largely coming through suits filed outside Delaware. There is some evidence that the out-of-Delaware trend began in the late 1990s, but strengthened around 2002. The trend toward more overall corporate litigation begins around 2002. There has also been a more recent trend, principally in the last two years of our sample period, toward suits concerning the same facts being filed in more than one jurisdiction.

Some caveats. First, some of the trends we document may reflect a general tendency for companies incorporated outside of their home state to be different in various ways from, or to be sued in ways that differ from, companies that incorporate at home, rather than a difference between Delaware law and the corporate laws of other states. In our regressions, we assess and discuss the extent to which our results for Delaware firms differ from "away-non-Delaware" firms. ${ }^{10}$ However, especially for LBOs, the number of away-non-Delaware firms is small, so we have limited statistical power to distinguish between these two groups.

Second, we study aggregate trends in corporate litigation. Those trends are dominated by shareholder lawsuits, and thus by the forum selection choices of plaintiffs' lawyers. Subclasses of corporate litigation might show different trends, if we had studied them. For example, we have no reason to think that suits by bidding firms against target boards have moved out of

10 Litvak (2012) stresses the importance of comparing Delaware public companies to other out-of-state incorporated public companies, rather than all public companies. 
Delaware. We do not study cases which interpret merger agreements, nor the forum selection clauses in these contracts, which govern where those cases are heard.

The rest of the paper is structured as follows. Section II provides background and a literature review. Section III describes our datasets. Section IV discusses general trends on litigation venue and litigation rates, focusing on Delaware companies. Section V presents regressions exploring whether these trends are unique to Delaware companies or shared with companies incorporated elsewhere. Section VI develops and tests hypotheses on the nature and possible precursors to these trends. Section VII briefly discusses implications for Delaware, and Section VIII concludes.

\section{BACKGROUND AND RELATED LITERATURE}

\section{A. Choice of Jurisdiction}

Delaware incorporation typically ensures that Delaware's substantive law will control in a suit under corporate law and that such a suit can be brought in Delaware. ${ }^{11}$ However, plaintiffs' lawyers can also file suit in any other court which has both subject matter jurisdiction over the claim and personal jurisdiction over the defendants. In practice, if a company incorporates outside its home (headquarters) state -- as is the case for almost all Delaware-incorporated companies -- the courts of the company's home state are nearly always available as a forum for both direct suits (including class actions) and derivative suits. ${ }^{12}$

The federal courts in the company's home state will normally have personal jurisdiction over its directors and officers, and thus offer a third potential forum. For derivative suits,

11 Ribstein and O'Hara (2008); Jacobs (2009). Directors and, since 2004, officers must consent to personal jurisdiction in Delaware as a condition of incorporation: 10 Del. C. $\S 3114(\mathrm{a})-(\mathrm{b})$.

12 States typically have courts of general jurisdiction, so subject matter jurisdiction is not a concern. Personal jurisdiction over the company's officers will normally be easy, since most will work and often live in the company's home state. The fact most companies hold at least some board meetings at their headquarters should provide the minimum contacts with directors needed for personal jurisdiction. 
diversity jurisdiction will usually be available and will provide subject matter jurisdiction. ${ }^{13}$ For direct suits, subject matter jurisdiction is harder to come by, but plaintiffs can sometimes combine a state law claim under corporate law with a related federal claim, often under securities law, and obtain "supplemental" (or "pendent") federal jurisdiction over the corporate law claim. $^{14}$

Defendants in corporate suits have some scope to challenge the litigation venue choices plaintiffs make. For Delaware companies, if suits involving similar facts have been filed both in Delaware and in the home state, the defendants could seek a stay or dismissal of the nonDelaware proceedings on forum non conveniens grounds. ${ }^{15}$ However, success on a forum non conveniens motion is not assured, with the chances decreasing if the case was filed first in that state court and there has been significant progress in the litigation. ${ }^{16}$ Moreover, defendants may choose not to seek a stay because they "do not wish to alienate potential fact-finders by openly fleeing one court for another."17

For cases brought in federal courts under supplemental jurisdiction, a federal judge may, in the interests of comity and judicial efficiency, dismiss or stay a derivative lawsuit where a single state court action would best serve the interests of the corporation and its stockholders. ${ }^{18}$

13 Newman (1969).

14 Kaplan (1976); United Mine Workers v. Gibbs 383 U.S. 715 (1966) (test for "pendent” jurisdiction; now included in "supplemental jurisdiction"); Finley v. United States 490 U.S. 545 (1989). For class actions in general, Congress has introduced various reforms designed to expand federal court jurisdiction, primarily the Securities Litigation Uniform Standard Act, Pub. L. No. 105-353, 112 Stat. 3227 (1998), codified in scattered sections of 15 U.S.C., and the Class Action Fairness Act, Pub. L. No. 109-2, 119 Stat. 4 (2005) (codified at 28 U.S.C. § 1453). But these statutes both contain "Delaware carve-outs" and do not cover corporate law cases. See Erickson (2008); Kahan and Rock (2005).

15 Note, Forum Shopping Reconsidered (1990); Bassett (2006).

16 Miller (1996).

17 Williams (2011), at *3.

18 See, e.g., Weiss v. Doyle, 178 F. Supp. 566 (S.D.N.Y. 1959). On the factors that influence stay decisions, see Rydstrom (1970). 
On the other hand, economizing on judicial resources could well imply that the federal case should proceed, and the state case should be stayed. Federal courts have denied applications for a stay of a derivative action when a related state court case has not been significantly litigated, and when the federal complaint was not a "mirror image" of the state court complaint. ${ }^{19}$

\section{B. $\quad$ Related Research}

In contrast to the extensive scholarly attention devoted to where companies incorporate, little research has been done on venue choice in corporate law, and none that studies time trends. For years, the conventional wisdom for both sides of the "incorporation debate" was that most corporate law cases involving Delaware public companies were in fact brought in Delaware. ${ }^{20}$ William Cary, famously characterizing Delaware as the winner in a "race for the bottom" for incorporation business, remarked on "the relative ease of entry into Delaware courts for suits against corporate directors." 21 Roberta Romano, a "race to the top" advocate, reported that "most Delaware firms are in fact sued in Delaware." 22 Romano's statement was based on a study of 139 shareholder suits brought between the late 1960s and 1987 against large public corporations. $^{23}$

19 Tabas v. Mullane, 608 F. Supp. 759, 763 (C.D.N.J. 1985) (application for stay dismissed on the basis there was "no previously filed, significantly litigated, or more advanced state action"); Loeb v. Whittaker, 333 F. Supp. 484, 489 (S.D.N.Y. 1971) ("mirror image").

20 See, e.g., Macey. and Miller (1987); Kamar (1998); Branson (1990).

21 Cary (1974), at 686.

22 Romano (1993), at 41.

23 Romano (1991). Of the 35 lawsuits in Romano's dataset that involved Delaware corporations and were not brought in federal court, 29 were filed in Delaware courts ( 24 exclusively). Of the 139 suits, 68 were brought in federal court; a substantial number of these suits likely involved Delaware companies. See Romano (1993), at 41. In hindsight, Romano's data suggest that the federal courts have been a significant venue for corporate lawsuits for some time, but as the quote in text suggests, neither she nor anyone else focused on this. Romano's original 1991 study does not discuss where studies were filed; the data we rely on here are mentioned only in her later book, and only in passing. 
In a prior study on the litigation risks faced by directors of public companies in the U.S. and the U.K., we compiled a dataset of cases in which directors of U.S. public companies were defendants in lawsuits under corporate law and the case generated at least one publicly available written judicial opinion over 2000-2007. ${ }^{24}$ The study's main U.S. finding was that only a small percentage of public company directors face a lawsuit that is sufficiently contentious to result in a reported written opinion. We also found, to our surprise, a decline over our study period in the proportion of cases decided by the Delaware courts. We conjectured that this might represent an "out of Delaware" trend. ${ }^{25}$

At the time of our prior study, the "out-of-Delaware" trend was known to some practitioners, ${ }^{26}$ but had not been documented, nor received significant academic attention. ${ }^{27} \mathrm{We}$ asked practitioners in 2008 and 2009 about the apparent trend. Early responses varied from (to paraphrase) "the trend absolutely exists and began in the late 1990s" to "what trend - there has been no falloff in Delaware litigation." As we will see, both responses are correct. The Delaware courts have been losing market share, likely since the late 1990s, but are not seeing fewer cases in absolute numbers.

Others have since also investigated choice of forum in shareholder suits. Brian Quinn studied litigation venue for 119 mergers between August 2009 and August 2010 with a public Delaware target and transaction value of at least $\$ 100$ million. ${ }^{28}$ Ninety-seven of these deals

24 ABCN (2009).

25 ABCN (2009), at 705.

26 The first public mention we are aware of is a news story reporting remarks at a practitioner conference by Ted Mirvis, a senior litigation partner at Wachtell, Lipton, Rosen \& Katz, who called this trend "Anywhere But Chancery" phenomenon, referring to the Delaware Court of Chancery. See Anywhere But Chancery: Ted Mirvis Sounds an Alarm and Suggests Some Solutions, M\&A Journal, May 2007, 17.

27 Two exceptions who noticed the trend, though neither provided data, were Lewis (2008) [student note] and Stevelman (2009).

28 Quinn (2012). 
were litigated (82\%). Of these, Delaware was the sole forum only 8 times. For 41 litigated deals, all suits were filed outside Delaware. Jennifer Johnson investigated 196 instances in 2010 where class actions were filed under state law involving Delaware public companies, of which all but three involved M\&A. ${ }^{29}$ These transactions gave rise to 265 suits, of which 103 were in Delaware, 115 were in other state courts, and 47 were in federal court. For 93 of her 196 firms, the plaintiffs avoided Delaware altogether. Matthew Cain and Steven Davidoff, using a sample of 995 M\&A transactions valued at over $\$ 100$ million between 2005-2010, report that some states grant higher fee awards than other states and plaintiffs' attorneys respond to these differences. ${ }^{30}$ They also report an increase in the fraction of transactions that attract suits from $39 \%$ in 2005 to $84 \%$ in 2010 . Finally, a study by Cornerstone Research, assisted by Prof. Robert Daines, reports that in 2010-2011, 95\% of public company mergers with value exceeding $\$ 100$ million attracted suits. ${ }^{31}$ The study notes that many suits involving Delaware companies are filed outside Delaware but indicates (without providing data) that the share of cases filed elsewhere did not increase between 2007 and 2011. None of these studies go back far enough in time to capture the start of the out-of-Delaware trend. Moreover, all study only suits challenging M\&A transactions, which are only one aspect of the overall trend we document.

A number of Delaware companies have responded to the out-of-Delaware trend by adopting choice of forum provisions in their bylaws or charters ex ante. Should such amendments be effective, they might stem the trend we document. However, they face

29 Johnson (2012). Johnson terms these suits "securities class actions," but they arise under corporate law, not securities law.

30 Cain and Davidoff ((2012b).

31 Cornerstone Research (2012). 
significant obstacles - partly legal, partly opposition from shareholders. We discuss these obstacles in a companion law review paper. ${ }^{32}$

A related line of studies have focused on forum selection clauses in merger agreements. Here, there is some tendency for Delaware to be the chosen forum if the target is incorporated in Delaware and publicly traded, but no such tendency for private targets. ${ }^{33}$ These involve clauses which are negotiated ex ante between the parties. This is a very different context from the ex post forum choice by plaintiffs' lawyers that we study here.

\section{DATA DESCRIPTION}

\section{A. Overview}

To provide a full picture of where corporate lawsuits involving Delaware companies are filed, we collect by hand four distinct datasets. Three of the four cover a period from roughly 1995 to 2010. The fourth - our "option backdating" dataset - involves a category of lawsuits filed mostly during 2006-2007 in response to a particular financial scandal. Our first two datasets cover, respectively, large M\&A transactions over 1994-2010, and leveraged buyouts over 19952010. These transactions are particularly likely to give rise to litigation. Both are predominantly direct actions by shareholders, brought as class actions. The third dataset comprises cases brought against directors of public companies that generated one or more publicly-available written judicial opinions during 1995-2009; these involve both direct and derivative suits. ${ }^{34}$ The option backdating dataset lets us focus on a group of important derivative lawsuits. Figure 1 summarizes the datasets and their strengths and limitations.

32 ABC Balancing Act (2012).

33 Cain and Davidoff (2012a); Eisenberg and Miller (2006); Coates (2012).

${ }^{34}$ To explain the differences in starting and ending dates for these samples: We rely on public filings; these were available back to 1994 for the larger companies involved in large M\&A transactions, but only back to 1995 for the smaller companies involved in most LBOs. We originally collected the judicial opinions dataset through 2009; we chose not to extend it through 2010 because of the large effort required, for limited return. 
[Figure 1 about here]

Each dataset has limitations. The SEC filings we rely on for the deals datasets do not include data on lawsuit outcomes in most instances; the sketchy data they provide are not suitable for quantitative analysis. The options backdating dataset is only cross-sectional. The opinions dataset cannot tell us about filing rates for the many cases that do not generate opinions. Moreover, most of the opinions in this dataset are preliminary judgments, not final outcomes. However, the combination of different datasets permits us to explore thoroughly the scope and robustness of the out-of-Delaware trend.

\section{B. The Large M\&A and LBO datasets}

Our goal with these two datasets was to study the evolution over time of case filing patterns. We chose these categories because prior research indicated that M\&A transactions (including LBOs) generate most corporate lawsuits in Delaware $-83 \%$ of cases filed in a two-year window reported by Thomas and Thompson. ${ }^{35}$ We focused on large M\&A transactions because prior studies find larger deals are more likely to be litigated, ${ }^{36}$ and on LBOs because of the conflicts of interest they generate between management and shareholders, which make these transactions both litigation-prone and sometimes a source of large dollar recoveries.

We obtained data on M\&A transactions from SDC Platinum. We extracted the largest 25 M\&A transactions by deal value for each year from 1994-2010 inclusive, which were categorised by SDC as mergers or tender offers with a US public company target. For LBOs, we included all transactions categorised by SDC as LBOs with a US public company target. We excluded deals not completed by 31 July 2011. We searched deal-related filings by the targets

35 Thompson and Thomas (2004a), tbl. 2 (952 fiduciary suits involving public companies, of which 796 involved acquisitions).

36 See, e.g.,. Krishnan, Masulis, Thomas and Thompson (2011). 
on the EDGAR website of the Securities and Exchange Commission for deal-related suits under corporate law. ${ }^{37}$ We gathered information on the progress of litigation from subsequent filings. We treated as a single consolidated suit all suits by target shareholders in a single jurisdiction involving the same transaction, whether or not these actions were formally consolidated. We did not treat as consolidated suits by bidders (these are direct, non-class-action suits) and suits by target shareholders (which were typically class actions), even if in the same jurisdiction. ${ }^{38}$

Table 1 provides an overview of the firms in our large M\&A and LBO datasets. The large M\&A dataset comprises 425 transactions (Panel A: 25 per year for 17 years). The LBO dataset includes 520 transactions (Panel B), with the number of transactions per year rising and falling with market cycles; annual totals range from 5 in 1995 to 67 in $2006 .{ }^{39}$ Table 1 indicates where each target was incorporated: Delaware, "home" (for incorporation in the "home" or "headquarters" state, if other than Delaware), and "away-non-Delaware" (for firms incorporated away from their home state, but not in Delaware). Roughly two-thirds of firms in both datasets were incorporated in Delaware. The away-non-Delaware proportion is only $13 \%$ for large M\&A transactions and $7 \%$ for LBOs. This limits our ability to distinguish Delaware-specific trends from trends that apply both to Delaware firms (almost all of which are incorporated outside their

37 We searched deal-related filings for "litigation" "lawsuit", "legal proceedings" and "class action". We then read the disclosure to confirm whether the suit was filed under corporate law, and excluded suits based solely on alleged breach of securities law, contract law (including breach of the merger agreement), tort law, or antitrust law. We excluded suits brought by the acquiror's shareholders against the acquiror or its board, because our search strategy was not designed to capture systematically these suits; suits brought by creditors; and suits filed more than 6 months after the deal closed. We dropped deals with no EDGAR data. In the large M\&A dataset we replaced them with the next-largest deals with data on EDGAR to obtain 25 deals per year. In a number of cases, deal-related suits were filed before the transaction was announced, and then amended after the announcement. We include these suits if they were filed less than 6 months before the deal was announced. There were 27 such suits for large M\&A transactions and 20 for LBOs.

38 There are 19 direct suits by bidders in the dataset.

39 The small totals of 5 LBOs from 1995 and 15 from 1996 may partly reflect limited availability of EDGAR filings for smaller target firms during these years. 
home state) and away-non-Delaware firms. ${ }^{40}$ Below, we refer to Delaware firms and away-nonDelaware firms together, with only slight inaccuracy, as "away incorporators."

For both datasets, firm sizes were broadly comparable across these three subsets. For example, amongst large $M \& A$ transactions, median deal value was $\$ 7.0$ billion for Delaware targets, $\$ 6.7$ billion for away-non-Delaware targets, and $\$ 6.3$ billion for home targets. The LBOs involved, on average, much smaller firms, with median deal values of $\$ 308$ million for Delaware firms, \$145 million for away-non-Delaware firms, and \$207 for home incorporators.

[Table 1 about here]

Table 2 provides descriptive statistics for the lawsuits in our large M\&A transaction and LBO datasets. Over the full time period, litigation rates across these two datasets were similar, at 48\% for large M\&As and 47\% for LBOs. In the large M\&A dataset, home targets had the highest litigation rate (53\%), with Delaware targets at $48 \%$ and away-non-Delaware targets at $42 \%$, although these differences in means were not statistically significant. ${ }^{41}$ In the LBO dataset, Delaware targets were significantly more likely to be sued, at $52 \%$, compared to $37 \%$ for home targets and $35 \%$ for away targets.

In the LBO dataset, home incorporators had a significantly lower risk of facing two or more suits, at only $6 \%$ versus $16-17 \%$ for the other groups. This risk was also somewhat lower for home incorporators in the large M\&A dataset, at $17 \%$ versus $22-23 \%$ for the other groups, although the difference was not significant. This difference is not surprising. For home companies, the home state is generally the only feasible state forum. In contrast, for away

40 Of the Delaware-incorporated firms only three of 282 large M\&A targets (Hercules Inc, Conectiv Inc and Beneficial Corp) and two of 339 LBO targets (International Specialty Products and Nortek) have Delaware as their home state. This is too few for us to distinguish these firms from other Delaware firms.

${ }^{41}$ Here and later in this paper, we assess the significance of differences in means at the $5 \%$ level, based on a two-sample $t$-test, unless specified otherwise. 
incorporators, both the home state and the state of incorporation are usually feasible state fora.

The availability of federal court in the home state as a forum typically does not depend on where the company is incorporated. So, for away incorporators, there are more places to be sued.

Consistent with prior research, ${ }^{42}$ a high percentage of these lawsuits were class actions:

$91 \%$ for the large M\&A suits and $98 \%$ for LBO suits; a few of these suits also included derivative claims. The number of suits generally varied from one to three; but three large M\&A deals attracted four suits each. ${ }^{43}$

[Table 2 about here]

\section{Option Backdating Dataset}

Given that our takeover datasets consist primarily of class action lawsuits, we sought to complement them by investigating a class of suits brought as derivative suits. A wave of option backdating lawsuits, brought principally in 2006-2007, offered a rare opportunity to collect information on a class of derivative suits, with others having already tracked down these suits. ${ }^{44}$

Prior to 2005, if companies granted employee stock options with an exercise price equal to the market price at date of grant, they did not have to record a compensation expense. ${ }^{45}$

Option backdating typically involved choosing the "grant date" retrospectively, using a date at which the company's stock price was at its lowest during a particular period. This amounted to pretending that an in-the-money (at the actual grant date) option grant was an at-the-money grant

42 Thompson and Thomas (2004a), tbl. 2 (acquisition-related fiduciary duty litigation in Delaware against public companies, 1999-2000: 765 class actions, 12 derivative actions and 19 direct actions).

43 In two of these cases (First Interstate Bancorp, 1995 and Caremark Rx Inc, 2006), both shareholder class actions and direct suits by bidders were launched in Delaware. In the third case, US WEST Inc (1999), shareholder suits were filed in two states (CA, NY), in addition to the state of incorporation (DE) and the home state (CO). SEC filings do not indicate the jurisdictional bases for these suits.

44 For the M\&A datasets, we could begin with a source of deals, and then search SEC filings for suits. In general, there is no comprehensive source of corporate lawsuits filed in all 50 states.

45 See Hall and Murphy (2003); Financial Accounting Standards Board, Statement of Financial Accounting Standards (SFAS) 123 (Revised), Share-Based Payment, 2004, available at http://www.fasb.org/summary/stsum123r.shtml. 
(at the notional earlier date), and thus recording neither the compensation expense to the firm nor compensation income to the employee required by accounting rules for an in-the-money grant. ${ }^{46}$ The existence of backdating at many companies came to light in 2005 , and led to numerous lawsuits, internal company investigations, restatements of financial results, SEC investigations, and a few criminal cases. Shareholders of companies that had engaged in option backdating could bring securities class actions, alleging misdisclosure under Rule $10 \mathrm{~b}-5,{ }^{47}$ or bring derivative suits, alleging breach of fiduciary duty. ${ }^{48}$ Derivative claims were more common because a 10b-5 action required proof that the misdisclosure was "material"; which was often hard to prove because the stock prices of corporations that disclosed backdating were often not greatly affected by these disclosures. ${ }^{49}$

We constructed a dataset of claims filed under corporate law involving option backdating by aggregating data from the following sources:

(1) A list compiled by Glass Lewis, a proxy advisory service, of companies which undertook internal investigations of backdating and whether litigation had been filed against them.

(2) A list of backdating suits compiled by D\&O Diary, a website run by Kevin La Croix, an attorney and partner in OakBridge Insurance Services, a D\&O insurer. ${ }^{50}$

46 For discussion of the options backdating scandal, see, e.g., Fried (2008); Abbott (2009).

47 17 C.F.R. $§ 240.10 b-5$ (2010). Cornerstone Research (2010), Fig. 3, reports that 40 such cases were filed between 2005 and 2008 .

48 Breaches were alleged by directors and officers who granted backdated options, boards which failed adequately to oversee the process, and directors and officers who received backdated options.

49 Ashby Jones, Firms Settle Backdating Suits: Some Private Cases End in Agreements; More Deals Ahead, Wall St. J., Nov. 19, 2007, A15.

50 See http://dandodiary.blogspot.com/2006/07/counting-options-backdating-lawsuits.html (last visited Feb. 7 , 2012). This source indicated whether there was a derivative suit, a securities suit, or both, and often provided details about the outcome of the suit. 
(3) Two plaintiff law firms which brought many backdating cases generously provided us with information about their own suits and where available, suits by other firms.

(4) Websites of a number of other plaintiff firms active in backdating litigation.

(5) Jessica Erickson generously shared with us her data from a roughly contemporaneous study of derivative suits in federal court; we extracted the backdating suits. $^{51}$

These sources yielded 165 companies that faced derivative option backdating suits. We obtained details about the suits from these sources, plus searches of the companies' SEC filings on EDGAR and web searches for particular companies. Of the 165 companies that faced options backdating derivative suits, $127(77 \%)$ were incorporated in Delaware. The earliest suit against a Delaware company was filed in 2002 and the latest in $2009 .{ }^{52}$ However, $90 \%$ of the suits against Delaware companies were filed in 2006-2007.

An important question, in assessing the policy implications of the out-of-Delaware trend and the threat it may pose to Delaware's dominance, is whether Delaware is losing good cases, or only nuisance cases. In interviews we conducted, both plaintiff and defense attorneys described the option backdating cases as often having good prospects of dollar recoveries; we confirmed their overall importance by following these cases through to final outcome, although settlements are not always publicly disclosed, so we may miss some.

\section{Judicial Opinions Dataset}

51 Erickson (2010).

52 This suit was initially brought on other grounds, and later amended to add an option backdating claim. 
In compiling the large M\&A, LBO, and option backdating datasets, we seek to capture all suits filed in a given category. Our judicial opinions dataset focuses on suits against company directors that generated one or more publicly available written opinions. This permits us to see whether there is a trend in cases which lead to judicial opinions, which may carry precedential value. That a case generated an opinion is also a marker for its potential importance. At the same time, most suits do not lead to publicly available opinions, and courts differ in their tendency to write opinions; Delaware and federal judges are generally viewed as much more likely than judges in other state courts to do so. Thus, this dataset is both selective and biased toward cases in Delaware and federal court.

To obtain our opinions dataset, we searched the Westlaw Allcases and Lexis Mega databases for opinions in corporate law cases brought in any US state or federal court involving public companies where one or more directors was named as a defendant and which produced at least one publicly available judicial decision between 1995 and $2009 .{ }^{53}$ If we found one opinion, we searched for prior opinions in the same case. If one case generated more than one decision, we assigned the case to a year based on the first decision, and excluded from the dataset all cases with initial decisions before 1995. We also searched the Delaware Chancery Court website, which contains all written judicial opinions issued in that court since July 1, 2000. It was not feasible to search other state court websites. The dataset should be complete (or nearly so) for Delaware cases from mid-2000 onwards, and reasonably (but less) complete for other cases.

53 This dataset extend a dataset covering 2000-2007 created by ABCN (2009), supra note 8, for an earlier project comparing litigation rates in the UK and US, and described in more detail there. We required that a decision include (i) "director" or "board"; (ii) "public" or "stock exchange" or "NASDAQ"; (iii) "shareholder or stockholder" in the same paragraph as "derivative" or "consolidat!" or "class action"; and (iv) "fiduciary" or "care" or "Revlon" or "fair dealing" or "buyout". This search choice was a compromise between the desire to capture most corporate decisions, and the need for a search strategy which would produce a reasonable hit rate when we read the underlying opinions to assess whether they should be in our dataset. If an opinion did not state whether the company was publicly traded, we verified its status using the SEC's EDGAR database. 
Our opinions dataset encompasses 704 cases over 1995-2009. Table 3 presents descriptive statistics. The average number of cases per year over the entire period was 47 , but year-to-year totals varied from a low of 14 in 1995 to 96 in 2007, and generally increased over time. In 540 of the 704 cases $(77 \%)$, the case involved a Delaware company. This percentage is similar to the option backdating cases and higher than the takeover datasets; it is biased upward by our using the Delaware Chancery Court website to search for Delaware court opinions, as well as the greater tendency of the Delaware courts to write opinions, compared to other state courts. $^{54}$

The opinions dataset includes a significant number of takeover cases (202 cases, 32\%), but also many derivative cases (439 derivative cases, 63\%), mostly not involving takeovers, and a fair number of direct, non-class-action suits (108 direct suits, 16\%), also mostly not involving takeovers. Thus, it provides a second window, with a time series dimension, into derivative cases.

[Table 3 about here]

We undertake the large effort to collect all four datasets because no single dataset can provide a full picture of corporate litigation. While one might question the evidence for an outof-Delaware trend that emerges from any one dataset, together they provide a compelling picture of a world in which most shareholder suits arising under corporate law involving Delaware companies no longer take place in Delaware. We turn next to that evidence.

\section{Time Trends: Graphical Presentation}

We present here an overview of time trends in where cases are filed. Because our large M\&A and LBO datasets include all cases filed in each category, they provide the best place to assess

54 For all datasets, the representation of Delaware firms is higher than Delaware's share of all public company incorporations. Bebchuk and Hamdani (2002), at 567-68 (58\% share as of 2000). 
time trends in where cases are filed. However, we present complementary findings for cases giving rise to judicial opinions and, without the time dimension, option backdating cases. In this section we offer a graphical assessment, focusing mostly on suits involving Delaware companies. In section $\mathrm{V}$ we turn to regression analysis to ascertain whether there are different trends for Delaware companies than for other away incorporators and/or home incorporators.

\section{A. Large M\&A Transactions}

1. Delaware targets: how many suits, and where?

Figure 2 shows the evolution over time of the number of suits challenging large M\&A transactions involving Delaware targets and where those suits were filed. Figure 2 presents the ratio of suits filed per year (separately for suits in Delaware, other state courts, and federal court) to the number of transactions involving Delaware targets in that year. It shows a strong upward trend, beginning in about 2001, in the litigation rate over time. By 2006, the ratio of suits to deals is one or higher, and by 2009, this ratio approaches 2:1.

[Figure 2 about here]

Figure 2 also provides evidence that the Delaware courts have been receiving a declining share of these suits. The bottom line of the Figure shows suits per deal in Delaware. This ratio is largely constant from the mid-1990s through 2007. Almost all of the growth in filings per deal over 2002-2007 occurs outside Delaware. After that, the number of suits per deal in Delaware also rises, as if plaintiff law firms collectively decided "let's sue in Delaware too".

To focus on trends in litigation share, Figure 3 reconfigures the data in terms of proportion of filings in Delaware, other state courts, and federal court, involving Delaware targets. It shows Delaware's declining share of suits against Delaware companies. That share is $60 \%$ or higher through 2001, but below $40 \%$ from 2002 on, drops to close to $20 \%$ in 2006 and 
2007, then recovers to $30-40 \%$ beginning in 2008, as the apparent "sue in Delaware too" trend takes hold. Figures 2 and 3, taken together, show that suits against Delaware targets have become increasingly common in both federal court and in other state courts, with most of the growth coming in other state courts.

[Figure 3 about here]

2. Delaware versus non-Delaware targets: litigation rates

How does the likelihood of suit for Delaware targets compare with that for non-Delaware targets? Figure 4 shows these likelihoods for both groups. There is a similar upward trend for both groups. By 2009, the likelihood of one or more suits exceeds $80 \%$ for both groups.

[Figure 4 about here]

3. Delaware versus non-Delaware targets: multi-forum litigation

The rise in suits outside Delaware involving Delaware targets may reflect a rise in multi-forum litigation: additional suits filed elsewhere, with a suit also filed in Delaware, additional suits elsewhere in deals that do not generate litigation in Delaware or some of both. To explore the relative role of these sources of non-Delaware suits, we now explore trends in litigation rates and multi-forum litigation.

Figure 5 shows the trend over time in the likelihood that a large M\&A transaction will generate more than one consolidated lawsuits, separately for Delaware and non-Delaware targets. As we treat as consolidated all suits that could be consolidated, the presence of multiple consolidated lawsuits in our dataset almost always indicates litigation in more than one forum. It will not do so only if suits filed are by the bidder and by shareholders in the same forum, with no suit in any other forum. This occurred for only one large M\&A transaction and no LBOs in our 
datasets. In each case, the proportion of deals generating multi-forum litigation is modest, with a fair amount of annual volatility, through 2005, but rises thereafter, with a sharp uptick in 2009.

Figures 4 and 5 reflect, in different ways, an underlying trend toward more litigation challenging large M\&A transactions. By 2008, the litigation rate for large M\&A transactions is approaching $100 \%$. At this point, the principal way in which more suits can be brought is through filing in additional forums for deals that have already attracted litigation. The relatively constant rate of multi-forum litigation through the mid-2000s, alongside growth in the fraction of litigated deals, suggests that the growth in non-Delaware suits shown in Figures 2 and 3 is driven by deals litigated outside Delaware, which in prior years would not have attracted suits.

[Figure 5 about here]

4. How often does Delaware get bypassed?

In Figure 6, we address directly the extent to which the growth in lawsuits against Delaware companies reflects multi-forum litigation — shared between Delaware and other jurisdictionsversus litigation that bypasses Delaware entirely. This figure shows how often Delaware has sole control of litigation, because a suit is filed only in Delaware; how often it has shared influence, because suits are filed both in Delaware and elsewhere; and how often it has no influence, because suits are filed only outside Delaware.

Figure 6 shows that through 2001, Delaware was often the sole forum, and was always $a$ forum, when a shareholder suit arising from a large M\&A transaction was filed. From 2002 on, it has rarely been the sole forum, and is sometimes not a forum at all. In the last five years of our sample period, from 2006-2010, Delaware was the sole forum for large M\&A shareholder litigation in only 3 instances - two in 2008 and one in 2010. The proportion of large M\&A transactions where Delaware had sole or shared influence fell sharply over 2002-2006, reaching 
a low of under $30 \%$ in 2006 . This proportion then rose again beginning in 2007, reflecting the "sue in Delaware too" trend noted above.

The middle section of Figure 6 - deals litigated both in Delaware and elsewhere - reflects multi-forum litigation: it bounces around but if anything decreases in the first part of our sample period, then rises sharply after 2005. In the earlier part of our sample period, the decline in deals litigated solely in Delaware largely reflects a rising proportion of deals litigated exclusively outside Delaware. In the last few years, Delaware recovers a share of increasingly multi-forum litigation.

[Figure 6 about here]

\section{B. LBO Dataset}

1. Delaware target companies: how many suits, and where are they filed?

Figures 7-11 are parallel in structure to Figures 2-6, but cover the LBO dataset. ${ }^{55}$ Figures 7 and 8 are limited to Delaware target companies. Figure 7 shows the evolution over time of the ratio of suits challenging LBOs involving Delaware targets to the number of these transactions, and where those suits are filed. The time trend is strongly and steadily upward. By 2006, the ratio of suits to buyouts is generally 1 or higher; after a dip in 2009, the ratio rises to 1.5 in 2010 (48 suits involving 32 buyouts).

[Figure 7 about here]

As Figure 7 shows, the growth in filings is driven primarily by cases filed in state courts other than Delaware's. This implies a strong decline in the Delaware courts' share of these suits. Unlike large M\&A transactions, there is only a modest countervailing "sue in Delaware too" trend over the last couple of years.

55 The LBO dataset begins in 1995, but there are no lawsuits for the small number of LBO deals in 1995 and 1996. We therefore limit Figures 8 and 11—which involve proportions of litigated deals — to begin in 1997. 
Figure 8 reconfigures the data in Figure 7 in terms of proportions of suits. It shows a steady drop in Delaware's share of suits against Delaware companies undergoing LBOs. During the late 1990s, a large majority of these suits were filed in Delaware. This proportion first fell below $50 \%$ in 2005 , and has generally continued to fall since then. The outside-Delaware growth comes principally in other state courts; federal court filings remain rare.

[Figure 8 about here]

2. Delaware versus non-Delaware targets: litigation rates

Figure 9 shows the likelihood that an LBO will attract one or more suits, separately for Delaware and non-Delaware companies. The pattern for non-Delaware companies is more irregular than for Delaware companies, perhaps with less of an upward trend through 2008, but by 2010, both groups face a close to $100 \%$ chance that the deal will be challenged.

[Figure 9 about here]

3. Delaware versus non-Delaware targets: multi-forum litigation As with large M\&A transactions, the rise in LBO-related litigation reflects a combination of a rising likelihood that a deal will be challenged somewhere, and an increase in multi-forum litigation. Figure 10 shows the trend over time in the likelihood that a LBO will generate litigation in multiple forums, separately for Delaware and non-Delaware targets. For both groups, multi-forum litigation is rare through 2001. It then jumps in 2002 for Delaware targets, and thereafter remains higher for Delaware than for non-Delaware targets. There is a further rise, this time for both groups, beginning around 2006.

[Figure 10 about here]

4. How often does Delaware get bypassed? 
Figure 11 is similar to Figure 6, and addresses whether, for LBOs of Delaware companies that attract lawsuits under corporate law, the Delaware courts have sole control (suit only in Delaware), shared influence (suit filed both in Delaware and elsewhere), or no control (suit filed only outside Delaware) over the outcomes of these suits. There is a steady fall in the proportion of sole-control LBOs, and a smaller but still substantial rise in the proportion of transactions for which suit is filed only outside Delaware. The middle "shared control" section of Figure 11 reflects the rate of multi-forum litigation presented in Figure 10: it grows for much of the period with a sharp uptick in 2009 and 2010.

[Figure 11 about here]

\section{Judicial Opinions Dataset}

We turn next to our dataset of cases generating publicly available written judicial opinions over 1995-2009. These cases often differ from the takeover lawsuits we studied above: only $32 \%$ involve M\&A transactions, and 63\% involve derivative suits.

Figures 12 and 13 focus on the 540 cases in this dataset involving Delaware firms.

Figure 12 shows that the number of opinions coming from the Delaware courts remained roughly constant over this period. ${ }^{56}$ In contrast, the number of opinions published by courts elsewhere has been rising. Viewed broadly, this is similar to the out-of-Delaware trends we saw for the two takeover datasets. The judicial opinions dataset provides evidence that the trend applies to derivative suits as well as class actions and other direct suits; and that it applies to cases that reach the stage of a written opinion. A key difference is that "elsewhere" for judicial opinions is usually federal court, while for takeovers, "elsewhere" was most often another state court. The greater federal share of the "elsewhere" opinions is likely due to several factors, including:

56 The somewhat larger number of Delaware decisions in the 2000s could reflect sample selection bias: We have $100 \%$ coverage of Delaware decisions from mid-2000 on, but prior to that rely on Westlaw and Lexis, whose coverage may be incomplete. 
derivative suits are easier than class actions to bring in federal court; federal judges are more likely to write opinions than most state court judges; and Westlaw and Lexis may be more likely to report federal decisions than state court decisions. ${ }^{57}$

[Figures 12 and 13 about here]

In Figure 13, we switch from counts to proportions. In 1995, over $80 \%$ of the cases in our judicial opinions dataset involving Delaware companies were heard in Delaware. This proportion dropped to below $50 \%$ by 2004 and has remained below $50 \%$ since, dipping below $30 \%$ in 2005 and 2008. Because our search strategy is biased in favor of finding Delaware cases from 2000 onwards, these percentages are an upper bound on the actual proportion of Delaware decisions in these cases. ${ }^{58}$

We investigated whether the trends in judicial opinions might simply reflect changes over time in the probability that opinions would be reported in Westlaw or Lexis. We estimated trends in the likelihood of reporting by counting the total number of Delaware, other state, and federal civil opinions reported in Westlaw for each year of our dataset. ${ }^{59}$ We would have preferred a measure limited to corporate or business cases, but were unable to construct such a measure. We found a large rise, by nearly by a factor of two, in reported federal opinions over May 2005-April 2007; there was no comparable change in the number of state court opinions. We then normalized the annual case counts in our dataset based on the ratio of total opinions in each of the three groups (Delaware, federal, other state court) to the number of opinions in 1995.

57 Martin (2008); Williams (1991).

58 A caveat: The total number of civil federal opinions per year on Westlaw nearly doubles over 2004-2006, which likely reflects a change in which cases the courts report to Westlaw, or which Westlaw reports. This change may have affected the number of corporate lawsuits found by our Westlaw and Lexis searches.

59 For federal civil cases, we started with the number of opinions for each year in the database ALLFEDS, then subtracted criminal cases, identified by the search query “:ti(state u.s. "united states" people) crim!". For cases in other states, we obtained the number of opinions for each year from the database ALLSTATE and subtracted the number of Delaware opinions. 
Figure 14 is similar to Figure 13, but uses the normalized annual totals. The growth in federal opinions is less pronounced, but Delaware's declining share is still very marked.

\section{Option Backdating Dataset}

As a check on whether the out-of-Delaware trend is present for non-takeover cases, often brought as derivative suits, and a further check on whether the Delaware courts are losing "good" cases, we turn to our dataset of option backdating derivative suits. In our dataset, 127 Delaware companies faced these suits, most often in 2006 or 2007 . Of these 127 firms, 101 (80\%) were sued only outside Delaware. Of the 26 companies that were sued in Delaware, only 4 (3\%) had suits exclusively in Delaware, and $22(17 \%)$ had derivative suits both in Delaware and elsewhere. The data confirm that for this class of derivative suits, plaintiffs' lawyers launching derivative suits involving Delaware companies often chose to file elsewhere.

One might usefully compare this pattern to that for the 38 non-Delaware companies which faced backdating suits. While only $11 \%$ of backdating suits against Delaware companies were filed in Delaware, the equivalent "in state" figure was $33 \%$ for the 31 home incorporators in our dataset, and $17 \%$ for the 7 away-non-Delaware firms; the difference between home and away incorporators is significant, but the difference between Delaware and away-non-Delaware firms is not. This suggests that there was a modest away-incorporator effect on where option backdating cases were brought, but does not support a Delaware-specific effect, compared to other away incorporators.

\section{TIME TRENDS: REgression ANALYSES}

We now turn from graphical to regression analyses of time trends. We focus first on the two takeover datasets, exploring trends in the likelihood of litigation occurring, likelihood of litigation in multiple fora, and likelihood of litigation bypassing the state of incorporation, 
respectively. To facilitate comparison, we present regression results from the large M\&A and LBO datasets side-by-side in the same tables. We then turn to the judicial opinions dataset to explore trends in the likelihood that judicial opinions are written by the courts of the state of incorporation. We cannot use the option backdating dataset because it does not have a time series component.

\section{A. Likelihood of litigation in takeover transactions}

Table 4 reports marginal effects (here and below, with other variables at their medians) from probit regressions of the probability that a deal will attract litigation. Regressions (1) to (5) relate to large M\&A transactions; regressions(6) to (10) use the same specifications, but relate to the LBO sample.

Regressions (1) and (6) are limited to Delaware targets. The principal independent variables are "time trend" (defined as 0 in the first year with data, which is 1994 for large M\&A transactions and 1995 for LBOs, 1 in the next year, and so on up to 2010; and $\ln$ (deal value in \$ millions). ${ }^{60}$ All regressions also include a constant term. ${ }^{61}$ In both regressions, there is a strong, statistically significant time trend toward greater likelihood of litigation. The coefficient on deal size is positive in both regressions, as one might expect, but significant only for LBOs. This is perhaps because the M\&A sample is already the 25 largest deals each year. Most of these transactions may already be at a size where other factors have greater marginal effects on plaintiffs' lawyers' decisions on whether to file suit.

60 The simple time trend variable treats any time trend as monotonic. Yet our Figures suggest that some of the trends over time may not be monotonic. For all regression tables, we conducted a robustness check by replacing the time trend term with year dummies, and visually inspecting the annual coefficients for apparent trends. The results were consistent with those we report.

61 We do not report coefficients for the constant term because the marginal effect is not defined. 
Regressions (2) and (7) are limited to targets incorporated in states other than Delaware. We include the same independent variables, and add a dummy "away incorp (not DE)", which equals 1 for away-non-Delaware incorporators. The results for large M\&A transactions in regression (2) are similar to regression (1): the coefficient on the time trend is similar to regression (1) and statistically significant. The rising litigation frequency for both Delaware and non-Delaware firms is consistent with Figure 4.

In contrast, for LBOs, the time trend in regression (7) is positive but much smaller than that for Delaware firms and not significant. In Figure 9, we saw that the proportion of nonDelaware LBOs that attracted litigation had greater annual variation than for Delaware LBOs and no clear trend through 2009, but then a large jump in 2010 to catch up to the Delaware firms. The positive but insignificant coefficient in regression (7) is consistent with that visual impression.

Regressions (3), (4), (8) and (9) include all firms in the respective datasets, wherever incorporated. In regressions (3) and (8) we add a "DE incorporation" dummy variable, which equals 1 for firms incorporated in Delaware and 0 otherwise. These regressions are mostly a way station before the specifications in (4) and (9), which also include interactions between time trend and the Delaware and away-incorporation dummy variables. For large M\&A deals, we see hints of a lower likelihood of suit for away-non-Delaware firms in regression (3), with a marginally significant negative coefficient on the away-non-Delaware dummy. There was a similar negative coefficient on this variable in regression (2).

The more interesting results are for LBOs, from regression (8). This regression provides evidence that Delaware companies face a greater average likelihood of being sued, but other away incorporators do not. These results could be driven by differences between the firms in the 
two subsamples. But suppose they are not. Could differences in corporate law plausibly explain these results? We think they can. Delaware law is strict on LBOs and other conflict-of-interest transactions. In particular, Delaware law makes it hard for directors to obtain dismissal of a suit prior to trial, and difficult to avoid review under the entire fairness standard, rather than the much looser business judgment rule. We have not canvassed the laws of other states, but some could well be more generous to defendants.

[Table 4 about here]

In regressions (4) and (9), we add interactions between the time trend and the Delaware and away-non-Delaware dummies. This lets us assess whether the time trend in likelihood of suit is different for home versus Delaware or away-non-Delaware incorporators. With this specification, the simple time trend variable captures the trend for home incorporators, the interaction terms capture any difference of the Delaware and away-non-Delaware groups from the home-incorporator trend. For large M\&A transactions, the time trends are similar for all three groups. The coefficients on the interaction terms are negative but insignificant. In contrast, in regression (9), for LBOs, the trend toward more likelihood of suit is stronger for the Delaware incorporators, reflected in a significant positive coefficient on the DE incorporation * time trend term. Consistent with regression (7), the coefficient on the time trend variable, which now represents only home incorporators, is positive but not statistically significant. The additional time trend for away-non-Delaware firms is positive but insignificant.

Regressions (5) and (10) are limited to away incorporators. They let us to focus on whether the differences between Delaware firms and other firms are specific to Delaware, or reflect an experience common to away incorporators, compared to home incorporators. We include a dummy variable for away-non-Delaware incorporation, and an interaction term 
between this dummy and the time trend. The coefficient on the general time trend now represents the effect for Delaware firms. In both regressions, the coefficient on this time trend variable is positive and significant, consistently with the other specifications. The marginal effect for away-non-Delaware * time trend is negative, hinting that Delaware-incorporated firms have experienced a greater rise in litigation over time than their counterparts incorporated away from home in other states, but is not statistically significant. Our sample of away-non-Delaware incorporators is small, especially for LBOs (13\% of the M\&A sample; $7 \%$ of the LBO sample). This makes it hard to achieve statistical significance for results involving this group.

To summarize: the likelihood of litigation for target firms rose over our study period, for both large M\&A and LBO transactions. For large M\&A transactions, this trend is not specific to Delaware-incorporated firms, or to away-incorporators. In contrast, for LBOs, we find evidence of more rapid growth in litigation likelihood for Delaware firms, most clearly as compared to home incorporators.

\section{B. Likelihood of takeover litigation in multiple fora}

We next investigate trends in which deals attract suits in more than one forum. Table 5 reports marginal effects from probit regressions of the probability that a deal will attract two or more suits. ${ }^{62}$ The regression specifications are the same as in Table 4 , the only difference is the dependent variable.

In regressions (1) and (6), which include only Delaware targets, there is a positive and significant time trend toward a higher likelihood of multi-forum litigation for both types of transactions. There is no similar trend in regressions (2) and (7), which are limited to non-

62 One can also assess the factors influencing the incidence of multiple suits using the number of suits as a dependent variable. In unreported regressions using both OLS and count models (Poisson and negative binomial), the results were qualitatively similar to those in Table 5. 
Delaware firms; the coefficients on the time trend variable are positive but insignificant and much smaller than for Delaware firms.

In regressions (3) and (8), we add dummy variables for Delaware and away-nonDelaware incorporation. For large M\&A transactions, both coefficients of both are positive, hinting at a higher likelihood that away incorporators will face multiple suits, but insignificant, while the time trend variable remains significant. However, these results hide a time trend that is much stronger for Delaware firms than for home incorporators. This trend appears in regression (4), where the coefficient on time trend (now the coefficient for home incorporators) becomes small and insignificant, while the additional trend for Delaware firms, reflected in the Delaware * time trend interaction term, is positive and significant. Regression (4) also offers mild evidence of a stronger trend for Delaware companies than away-non-Delaware incorporators. The coefficient on away-non-Delaware * time trend is smaller than for Delaware * time trend and not significant. The same hint of a stronger trend for Delaware firms - but only a hint -- is seen in regression (5), which includes only away-incorporators. The coefficient on the general time trend--now representing Delaware firms--is positive and strongly significant, whereas the coefficient on the interaction term away-non-Delaware * time is negative but not significant. As in Table 4, the small number of away-non-Delaware firms limits our ability to find a significant difference between these firms and Delaware firms.

Turning to LBOs, in regression (8), the coefficient on the Delaware dummy is positive and significant, but smaller in magnitude than the coefficient on the away-non-Delaware dummy; the difference in coefficients is not significant. This suggests that away-incorporated firms — whether in Delaware or elsewhere — undergoing LBOs were more likely to attract litigation over the whole sample period than home incorporators. In regression (9) we add 
separate time trends for each group. We find a positive and statistically significant positive coefficient on the away-non-Delaware dummy, offset by a negative and marginally significant coefficient on away-non-Delaware * time trend.

In regression (10) we drop home incorporators and focus on differences between Delaware and away-non-Delaware firms. The coefficient on the time trend variable-now representing Delaware firms only_is positive and significant. Consistent with regression (9), the coefficient on away-non-Delaware * time is negative and marginally significant. The combined effect for away-non-Delaware firms is close to zero $(0.0215$ from the non-interacted time trend plus -0.0269 from the interacted time trend $=-0.0054)$. Thus, Delaware firms undergoing LBOs experienced an increase over time in the probability of facing multiple suits, while away-non-Delaware firms did not. However, the positive—although not significant— coefficient on the away-non-Delaware dummy suggests that these firms had a greater probability of multi-forum litigation over the entire sample period. The larger coefficient on away-nonDelaware than on Delaware in regressions (8) and (9) support this interpretation. A plausible interpretation is that away-non-Delaware firms had a higher initial probability of multi-forum litigation, but the increase over time was greater for Delaware firms.

[Table 5 about here]

In sum, regression analysis confirms the trend towards greater incidence of facing multiple suits - almost always in more than one jurisdiction. This pattern complements the trend toward a higher proportion of deals being litigated. For the proportion of deals litigated there was a general trend for large M\&A targets and a stronger trend for away-incorporated LBO targets, perhaps stronger for Delaware firms than other away-incorporators. For the likelihood of multiple suits, there is a general upward trend for LBO targets, which is greater for Delaware 
firms than for away-non-Delaware firms, and a trend for M\&A targets that exists principally for firms incorporated away from their home state, which is also likely stronger for Delaware targets than for away-non-Delaware targets.

\section{Likelihood of takeover litigation that bypasses the state of incorporation}

In Table 6, we report marginal effects from probit regressions in which the dependent variable is the probability that a deal will attract litigation only outside the target's state of incorporation. The specifications are otherwise the same as in Tables 4 and 5. In regressions (1) and (6), which are limited to Delaware companies, the coefficient on the time trend is positive and statistically significant. This confirms the visual impression from figures 6 and 11 of a rising likelihood that takeover litigation involving Delaware companies will bypass Delaware entirely.

There is evidence that this trend is largely Delaware specific. Regressions (2) and (7) provide initial evidence; they show no similar trend for non-Delaware companies. The harder question is whether we can distinguish Delaware trends from those for other away incorporators. In regression (3) and (8), the average likelihood of bypass is higher for away-incorporators, as expected, but this does not tell us about relative trends.

In regressions (4) and (9), we assess time trends separately for home incorporators, Delaware firms, and away-non-Delaware firms. The non-interacted time trend gives the effect for home incorporators. This effect is small and insignificant. Indeed, our datasets include only three large M\&A transactions and one LBO in which a home incorporator is sued exclusively outside its state of incorporation. ${ }^{63}$ The small number of these cases is unsurprising, because

63 In the M\&A dataset, Conrail Inc (acquired in 1996) and AMP Inc (acquired in 1998) were both incorporated in Pennsylvania but suits were filed only in federal court in Pennsylvania. Biogen Inc, incorporated in Massachusetts and acquired in 2003, was sued solely in California state court. In the LBO dataset, Ace Cash Express Inc, bought out in 2006, was incorporated in Texas but was sued only in federal court in Texas. 
plaintiffs often have no other forum option - both federal courts and other state courts are often unavailable.

For large M\&A transactions (regression (4)), as between the Delaware and away-nonDelaware groups, the time trend is larger and statistically stronger for the Delaware firms. The overall time trend for away incorporators (the sum of the coefficients on the time trend and away-non-Delaware * time trend variables) is close to zero. In regression (5), we limit the sample to away-incorporated firms. The marginal effect for the overall time trend, which now represents Delaware firms, is positive and strongly significant. In contrast, there is a negative and marginally significant coefficient on the away-non-Delaware * time trend interaction, and the combined marginal effect for these firms is close to zero (.0205 from non-interacted time trend plus -.0198 for interacted time trend $=.0007)$. Thus, the trend toward bypass exists only for Delaware firms.

[Table 6 about here]

For LBOs, in regression (9), none of the time trend coefficients are significant. The more interesting regression is (10), where we limit the sample to away incorporators. Similar to large M\&A transactions, the marginal effect for the overall time trend, which now represents Delaware firms, is positive and strongly significant. In contrast, there is a significant negative coefficient on the away-non-Delaware * time trend interaction, and the combined marginal effect for away-non-Delaware firms is negative (.0258 from non-interacted time trend plus -.0386 for interacted time trend $=-.0128$ ). Thus, the bypass effect is present only for Delaware firms.

For both datasets, the coefficients in regressions (3) and (8) for away-non-Delaware dummy, which capture an average effect over the sample period, are positive and larger in magnitude than the coefficients for Delaware dummy. This, combined with the trend toward 
bypassing Delaware and no similar trend for away-non-Delaware firms, suggests that early in our sample period, the Delaware courts had greater salience as a forum to litigate corporate law matters than courts in other away-incorporation states. However, this difference eroded over the time period we study.

In sum, both for large M\&A and LBO transactions, Delaware is increasingly being bypassed as a litigation venue. These trends appear to be specific to Delaware firms, with no similar trend for other away incorporators.

\section{Judicial Opinions}

We now turn to our judicial opinions dataset to see whether we find similar time trends to those in the takeover datasets. Table 7 presents marginal effects from probit regressions of the probability that a case generating an opinion will be in a jurisdiction other than the state of incorporation. To control for the growth in the reporting of federal civil opinions in electronic databases over time, noted earlier, we introduce an explanatory variable based on the annual number of federal civil case opinions in Westlaw. ${ }^{64}$ The specifications are otherwise similar to those in Tables 4-6.

In regression (1), which is limited to Delaware firms, there is a statistically significant growth over time in the likelihood that a judicial opinion in a will be written by a non-Delaware court. This is consistent with the out-of-Delaware trend observed visually in Figures 12-13. In regression (2), in contrast, there is no similar trend for non-Delaware firms.

[Table 7 about here]

\footnotetext{
${ }^{64}$ To limit colinearity between the measure of growth in federal civil opinions and our overall time trend variable, we do not use the raw number of federal civil opinions reported, but rather the residual from regressing the annual number of federal civil opinions on time trend plus constant term. In unreported robustness checks, we obtain similar results if we omit the federal cases variable.
} 
Regression (3) assesses the average effect over our sample period of being incorporated away from home. Over the whole period, the coefficient on the Delaware dummy is negative and the coefficient on the away-non-Delaware dummy is positive. Since there is a time trend only for Delaware opinions, this implies that Delaware-incorporated firms were less likely to have an opinion written by a non-Delaware court than other away-incorporators at the start of our sample period - and, therefore, more likely to have an opinion written in the state of incorporation. This tendency had reversed by the end of the period. ${ }^{65}$

In regressions (4) and (5), we study time trends, instead of average levels. In regression (4), the coefficient for the main time trend—which now represents home-incorporators—is small and insignificant. So is the coefficient on away-non-Delaware incorporators * time trend. In contrast, the coefficient for the Delaware * time trend interaction is positive and significant, indicating a trend toward decisions involving Delaware firms being written elsewhere. Regression (5), which is limited to away incorporators, provides a similar message. The coefficient on time trend, which now captures the Delaware trend, is positive and significant. In contrast, the coefficient on away-non-Delaware * time trend, which captures the difference between Delaware and away-non-Delaware firms, is negative and marginally significant, and the overall effect for away-non-Delaware firms is close to zero. Thus, Delaware is losing market share in opinions for Delaware companies, but other incorporation states - whether for firms that incorporate at home or firms that incorporate away but not in Delaware, are not.

In regression (5), the coefficient for away-non-Delaware incorporation is positive and strongly significant, indicating a higher likelihood at the start of our sample period that awaynon-Delaware incorporators will have an opinion written outside the state of incorporation.

\footnotetext{
${ }^{65}$ We so conclude, because coefficient on time trend in regression $(1) *$ (no. of years in sample period -1$)>$ difference between the coefficients on away-non-Delaware and Delaware dummies.
} 
Many of these opinions likely come from federal courts, given the relative tendencies of federal courts and non-Delaware state courts to write opinions in the first place.

In sum, Delaware companies faced a rising probability over our study period that opinions in cases against their directors would be written by courts outside Delaware. This trend is limited to Delaware.. At the start of our sample period, away-non-Delaware incorporators faced a higher probability than Delaware companies of having such an "outside" opinion; these relative tendencies had reversed by the end of our time period.

\section{E. Summary}

The results presented in Sections V.A-D support several interrelated effects. For takeover litigation, there is first, a secular increase in the likelihood that a deal will be challenged; second, an increase in the probability that suits will be filed in multiple fora in takeovers; and third an increase in the likelihood that the litigation will entirely bypass the state of incorporation. The

third effect is complemented by a trend we find for our judicial opinions dataset, toward a higher likelihood that an opinion will be written by a court other than the courts of the state of incorporation. Within these general effects, we identify the following Delaware-specific effects.

Delaware firms receive more suits. Delaware firms are more likely to be sued, and more likely to face multiple lawsuits, than home- incorporators. The rise over our sample period in the likelihood that a suit will be challenged is general to all M\&A targets, including home incorporators. The LBO trend exists for away-incorporators (including Delaware firms) but not home incorporators. We find a rise in multiple forum litigation for all LBO targets, but only away-incorporated M\&A targets. We generally do not find significant differences between Delaware and away-non-Delaware firms. But Delaware firms are increasingly more likely to be sued, and more likely to face multiple lawsuits, than home- incorporators. 
Delaware courts are getting a smaller fraction of suits and writing a smaller fraction of corporate law opinions. As regards the third and fourth effects, the time trend towards takeover litigation bypassing the courts of the state of incorporation exists for Delaware companies and only these companies. There is a similar pattern as regards judicial opinions: the likelihood that an opinion in a corporate law case will be written by the courts of the state of incorporation declines for Delaware companies, and only these companies.

\section{Why Is Delaware Losing CASes?}

\section{A. Development of Hypotheses}

In this section, we explore possible explanations for the trends identified in Sections IV and V. To develop intuitions, we surveyed literature and news reports, and conducted a series of telephone interviews with leading litigators involved in corporate suits, on both the plaintiff and defense sides. ${ }^{66}$ This yielded two testable hypotheses. Both involve changes in how the Delaware courts respond to plaintiff lawyers. These changes should only affect Delaware companies. The regression results above leave some ambiguity as to when litigation patterns are specific to Delaware companies, or apply more broadly to all away incorporators. Testing "Delaware-specific" hypotheses can add clarity to this issue as well.

66 Our interviewees were selected in order to give a range of perspectives that encompassed both "plaintiff side" and "defense side" work, with geographical bases both in and out of Delaware: Plaintiff bar: Randall Baron and Travis Downs (Robbins Geller Rudman \& Dowd LLP, San Diego office), Stuart Grant (Senior Partner, Grant \& Eisenhofer, based in Wilmington office); William Lafferty (Morris, Nichols, Arsht \& Tunnell LLP, Wilmington office); Joe Metzler and Lee Rudy (Kessler Topaz Metzler \& Check LLP); Bryn Vaaler, Peter Carter and Roger Magnuson (Dorsey \& Whitney, Minneapolis office); Defence attorneys: Ted Mirvis (Wachtell Lipton Rosen \& Katz, New York); Steve Radin (Weil Gotshal LLP, New York office); James Ducayet (Sidley Austin LLP, Chicago office). Interviews were semi-structured: we sent participants a detailed list of questions in advance, which formed the basis of the conversation, but they were free to pursue topics they considered to be relevant. We took contemporaneous notes. 


\section{More intensive fee scrutiny}

Fees are an important factor in lawyers' choice of where to file suit. ${ }^{67}$ Recent Delaware court rulings indicate willingness to scrutinize intensively fee requests by plaintiff lawyers. This trend emerges during our sample period. ${ }^{68}$ Traditionally, Delaware judges used the relief obtained by plaintiff lawyers as the primary benchmark for fee awards. This was widely believed to be more generous than the "lodestar" formula used in most other states, where fee awards were based on hours devoted to a case. ${ }^{69}$ Empirical studies reported that the Delaware Court of Chancery usually endorsed the full amount of agreed attorneys' fees in class actions and derivative suits with Delaware judges more than once authoring the studies themselves. ${ }^{70}$ This generous approach to fees went hand in hand with the Delaware judges' positive assessment of the role played by plaintiff attorneys in bringing shareholder suits, which Chancellor Chandler described in a 1999 case as "a cornerstone of sound corporate governance.",71

There was a change of heart beginning in 2001. Chancellor Chandler, in a paper written that year, confirmed that Delaware judges typically approved attorney fee proposals, but indicated unease, saying that "in the absence of an adversarial process at the fee award stage, judges in a common law system do not have the tools necessary to make consistently reasonable

67 See, for example, Committee on Securities Litigation (2008); Zywicki (2006); Coffee (1986).

68 ABC Balancing Act (2012); Micheletti and Parker (2012).

69 Macey and Miller (1987); Branson (1990).

70 Berger and Pomeroy (1992) (two-thirds of fee applications granted in full) (Carolyn Berger was a ViceChancellor of the Delaware Chancery Court); Chandler (2001) (two-thirds of fee petitions in settlements over 19982001 granted in full; others reduced on average by 20\%) (William Chandler was Chancellor of the Delaware Chancery Court); Weiss and White (2004) (settlements from 1999-01 merger cases; fees awarded in full in 40 of 47 merger-related cases over 1999-2001).

71 In re Fuqua Industries, Inc. Shareholder Litigation, 752 A.2d 126, 133 (Del. Ch. 1999). 
and fair judgments." ${ }^{, 72}$ Later that year, Chandler reduced a $\$ 24.75$ million fee to only $\$ 12.3$ million, in an M\&A case, Digex, where the plaintiffs secured a $\$ 180$ million settlement. $^{73}$

Other fee cut cases followed, accompanied by sceptical rhetoric about plaintiff lawyers. One was Cox Communications, which involved a going-private transaction. ${ }^{74}$ Vice-Chancellor Strine granted plaintiffs' attorneys only one quarter of the $\$ 5$ million fees they had requested (to which the defendants had agreed), and expressed misgivings about both shareholder class actions and the plaintiffs' bar. He noted that: ${ }^{75}$

Particularly in the representative litigation context, where there are deep concerns about the agency costs imposed by plaintiffs' attorneys, our judiciary must be vigilant to make sure that the incentives we create promote integrity and that we do not, by judicial doctrine, generate the need for defendants to settle simply because they have no visible alternative, even when they have done nothing wrong.

A series of cases with fee cuts, sceptical rhetoric, or both, followed. ${ }^{76}$

The Delaware judges maintain they will support generous fee awards where lawyers have brought a good case and achieved good recoveries. A striking example is the recent Southern Peru Copper Co litigation, in which (now) Chancellor Strine awarded the plaintiff lawyers a fee of \$285 million, the largest amount ever awarded to counsel in a corporate lawsuit. ${ }^{77}$ The

72 Chandler (2001).

73 David Marcus, Half a Loaf is Still Plenty of Bread, DeL. L. WeEKLy, May 29, 2001, at 1; see also Thompson and Thomas (2004b).

74 In re Cox Communications Inc., Shareholders Litigation 879 A. 2d 604 (Del. Ch., 2005).

75 Id. at 643 .

76 See eg, In re Instinet Group Inc., Shareholders Litigation (Del. Ch., Dec. 14, 2005) (\$1.62 million fee request reduced to \$450,000, 28\%); In re Cox Radio Inc. * 51 (Del. Ch. May 6, 2010) at* 50-56 (\$2.6 million fee request reduced to $\$ 490,000$ ); Brinckerhoff v. Texas Eastern Products Pipeline Company (Del. Ch. Jan. 15, 2010) (\$19.5 million fee request reduced to $\$ 10$ million); see also ABC Balancing Act (2012).

77 Martha Neil, Big Payday for Shareholder Suit Lawyers: Del. Chancery Court Awards \$285m Attorney's Fee, ABA Journal, December 19, 2011. See also Louisiana Municipal Employees' Retirement System v. Fertitta, Civ. No. 4339-VCL, Settlement Hearing, at* 21, 25 (Del. Ch., Oct. 6, 2010) (\$12 million fee "reasonable and well 
Delaware judges appear to be using fee scrutiny to encourage what they perceive as good cases and discourage bad cases from being brought in Delaware. Yet by any measure, Digex was a good case, with a large recovery.

Increased scrutiny of fee awards could foster a reduced propensity by plaintiffs' lawyers to file suit in Delaware in cases involving Delaware targets. We identify Digex as the first instance in which Delaware Courts showed a clear willingness to rein in plaintiff attorney fee settlements, and Cox Communications as the first in a line of cases involving both fee cuts and outspoken rhetoric against certain aspects of the plaintiffs' bar. Non-Delaware targets should not have been affected by these decisions, so form a control group. The subgroup of away-nonDelaware targets form an alternate control group. They are likely better matched, but there are fewer of them, making it harder to find statistically significant differences.

Hypothesis 1: ("Fee scrutiny”). The tendency of plaintiffs' lawyers to file suit against Delaware targets outside Delaware should increase after the Digex fee ruling, the opinion in Cox Communications, or both, relative to one or both control groups (all non-Delaware targets and away non-Delaware targets).

\section{Selection of lead counsel}

Multiple lawsuits based on the same facts are often filed in the same jurisdiction. ${ }^{78}$ The courts in that jurisdiction normally consolidate these suits into a single suit and appoint lead counsel, who will do most of the work and receive most of any fee award. ${ }^{79}$ Lead counsel is thus a coveted

earned.") The Southern Peru Copper fee award was under appeal to the Delaware Supreme Court when this article was finalized.

78 For our large M\&A dataset, in cases where at least one lawsuit was filed, Delaware targets received an average of 6.3 lawsuits per deal, before actual or notional consolidation of multiple filings in the same jurisdiction. The equivalent figure for LBOs was 3.2.

79 Thompson \& Thomas (2004a); Fisch (2002). 
position. A change in the approach by Delaware judges to selecting lead counsel, starting in 2000, might have encouraged some plaintiffs' firms to file suits outside Delaware.

Traditionally, Delaware courts took a hands-off approach to determining lead counsel, leaving it to plaintiffs' lawyers to sort this out amongst themselves. ${ }^{80}$ The plaintiffs' bar responded with a simple organizing principle: the firm who filed first should be lead counsel. This engendered a race to the courthouse. ${ }^{81}$ However, in 2000, the Delaware courts started to weaken the first-to-file presumption. In TCW Technology Ltd Partnership v. Intermedia Communications, Inc. ${ }^{82}$ the Court of Chancery was asked to decide which law firm should be lead counsel. Chancellor Chandler refused to apply the first-to-file "custom" and instead identified a list of substantive factors a Delaware court would consider. ${ }^{83}$

Our interviewees told us that the first-to-file custom remains important elsewhere. When plaintiffs' lawyers cannot resolve for themselves who should be lead counsel, judges outside Delaware often appoint as lead or co-lead counsel the firm that filed first. ${ }^{84}$ Consequently, since TCW Technology, filing first has probably been more valuable to plaintiff lawyers outside than inside Delaware. This could create incentives for some lawyers-especially smaller firms, without established track records in Delaware - to race to file outside Delaware.

80 CAB Plaintiffs' Bar (2012); Weiss \& White (2004).

81 CAB Plaintiffs' Bar (2012); Fisch (2001); Thompson \& Thomas (2004a), at 182-83 (of 623 deal-related class actions filed in Delaware in 1999-2000, 70\% were filed within 3 days of deal announcement); Weiss \& White (2004), 1827 (of 104 class actions challenging mergers involving Delaware targets over 1999-2001, 77 had their first suit filed within one day of merger announcement).

82 TCW Technology Ltd. Partnership v. Intermedia Communications, Inc., 2000 WL 1654504 (Del.Ch., Oct 17, 2000). This case arose from the same Digex transaction that prompted the ruling on attorneys' fees discussed earlier.

${ }^{83}$ These were the quality of the pleadings, the energy and enthusiasm demonstrated by the various attorneys, and the size of the economic stake each plaintiff had in the litigation.

84 Quinn (2012), at 22; Lebovitch, Silk and Friedman (2011), at 3 ; Rubenstein, Conte and Newberg (2002), at $\S 9.35$ No statute or procedural rule directly gives the courts authority to appoint lead counsel but MacAlister v. Guterma 263 F.2d 65 (2d Cir., 1958) is commonly cited as supporting this power: Fisch (2001), at 56, n.17. 
If both Digex (in 2001) and TCW Technology (in 2000) encouraged and subsequent cases encouraged filing outside Delaware, it will be challenging to separate these effects, because the two cases are close in time (indeed, both arose out of the same transaction). One way to distinguish the two is to focus on the timing of filing. If a change is due to the decreasing significance of first-to-file in Delaware relative to elsewhere, we might expect to see a drop in time-to-filing for suits against Delaware targets filed outside Delaware, as plaintiff lawyers whose comparative advantage is racing to file first shift to jurisdictions other than Delaware. However, because the $T C W$ decision affected only Delaware targets, non-Delaware targets form a control group; we expect no similar reduction in time to file for these firms. Once again, awaynon-Delaware incorporators form a narrower control group, better matched but smaller.

Hypothesis 2: ("First-to-file"). After the $T C W$ decision, the time-to-filing of suits against Delaware targets filed outside Delaware should drop relative to relative to one or both control groups (all non-Delaware targets and away non-Delaware targets).

For both hypotheses, our analysis can be understood as "difference-in-differences", using both a broad and a narrow control group. For both, we have only one treated state (Delaware), and cannot rule out the potential for other Delaware-specific factors to explain our results.

\section{Other conjectures}

Other explanations might exist; the two above are the ones for which we believe that we can construct plausible tests given our data. ${ }^{85}$ Ted Mirvis, a litigation partner at Wachtell Lipton, suggests that corporate lawsuits have greater settlement value outside Delaware due to greater variation in possible outcomes. ${ }^{86}$ He argues that outcomes in Delaware are more predictable due to the judiciary's familiarity with both the precedents and the conduct expected of the principal

\footnotetext{
85 We discuss other explanations more fully in ABC Balancing Act (2012), and only summarize here.

86 Anywhere But Chancery (2007), supra note 26.
} 
corporate actors. This conjecture is plausible, but seems unlikely to explain the time trend we document. Greater certainty would have been a feature of Delaware litigation in 1995, as much as today. ${ }^{87}$

Another possible explanation for plaintiffs filing outside Delaware is that Delaware judges are said by some to favor corporate defendants. ${ }^{88}$ Plaintiffs' lawyers told us that the likelihood of finding a sympathetic judge or, outside Delaware, a sympathetic jury, is a factor in their decisions on where to file. But the claim that Delaware courts favor management is an old one, and does not seem capable of explaining the recent time trend. ${ }^{89}$

Another potentially significant change within Delaware during our sample period was the extension, effective 1 January 2004, of Delaware's statute providing personal jurisdiction over directors of Delaware firms to include officers. ${ }^{90}$ This would, if anything, have increased Delaware's attractiveness to plaintiffs' lawyers.

Some potential explanations for the out-of-Delaware trend involve factors not specific to actions by the Delaware courts or legislature. The most significant relate to the organization of the plaintiff"s bar. The Private Securities Litigation Reform Act ("PSLRA") of 1995 required that securities class action plaintiffs advance a detailed factual pleading and introduced a presumption that the lead counsel role should go to the law firm with the largest client based on shares of the target company held. ${ }^{91}$ As we explore in detail elsewhere, these requirements drove many smaller, less well-capitalized firms out of securities fraud cases; some shifted to

87 See, for example, Macey \& Miller (1987); Romano (1993); Kaouris (1995).

88 Lebovitch, Silk \& Friedman (2011)88.

89 See, for example, Cary (1974).

90 Act of June 30, 2003, 74 Del. Laws c. 83 (codified at DEL. CODE tit. 10, § 3114(b)).

91 Pub. L. No. 104-67, 109 Stat. 737. 
corporate litigation. $^{92}$ In addition, during the mid-2000s, various large plaintiff firms who had specialized in securities litigation began to put greater emphasis on corporate suits. With the field becoming increasingly crowded, some firms seeking an edge in the lead counsel tournament might have decided to file outside Delaware. Greater competition among plaintiffs' lawyers may have contributed to the upward trend in litigation frequency and multiforum litigation we document above. But these trends do not give rise to hypotheses we can test with our data.

\section{B. $\quad$ Testing Hypothesis 1 on Fee Scrutiny}

Hypothesis 1 predicts that after Digex, and perhaps also after Cox, plaintiff lawyers come to expect Delaware courts to scrutinize fee awards more intensively, and become more likely to file elsewhere. We would expect this to show up most clearly in an increased probability for Delaware firms, relative to non-Delaware firms that litigation in a particular deal will take place entirely outside the state of incorporation.

[Table 8 about here]

Table 8 reports marginal effects from probit regressions of the probability that shareholder litigation in a takeover in our large M\&A or LBO datasets will entirely bypass the courts of the target's state of incorporation. Regressions (1)-(4) involve large M\&A transactions; regressions (5)-(8) use similar specifications but involve the LBO dataset. The independent variables are year fixed effects, $\ln ($ deal value), a Delaware incorporation dummy, a constant term, Digex * DE (a dummy variable which equals 1 for transactions involving a Delaware target announced after the Digex fee decision on April 6, 2001, and 0 otherwise), and Cox* DE

92 CAB Plaintiffs' Firms (2012). 
(defined similarly, equals 1 for transactions involving Delaware targets announced after the opinion in Re Cox Communications on June 6, 2005, and 0 otherwise). ${ }^{93}$

In regressions (1) and (5), the sample is restricted to away incorporators. The coefficient on Digex* DE captures the difference, after versus before Digex, in the likelihood that Delaware targets will be sued only outside Delaware. The year fixed effects capture general trends in the likelihood that targets will be sued only outside their state of incorporation. The Digex * DE coefficient is positive and statistically significant for both datasets, indicating a higher postDigex likelihood of bypass for Delaware targets, relative to the narrow control group of awaynon-Delaware targets. The coefficient on the Delaware dummy captures the pre-Digex difference in this likelihood between Delaware firms and other away incorporators. This coefficient is negative, suggesting that bypass was less common for Delaware firms prior to Digex, but is not statistically significant.

In regression (2), we expand the sample to include all firms, thus using the broader control group of all non-Delaware firms, with similar results; the estimated marginal effect strengthens for large M\&A transactions and weakens to marginal significance for LBOs. We thus find empirical support for Hypothesis (1), with respect to Digex. We caution that we cannot distinguish very well between a change due to Digex (in 2001) versus a change due to TCW (in 2000) or a combination of both; nor, for that matter, any other roughly contemporaneous change that affects Delaware firms differently than non-Delaware firms.

Regressions (3) and (4) track the specifications in (1) and (2) for large M\&A transactions, but focus on Cox Communications. Regressions (7) and (8) for LBO transactions are likewise similar to regressions (3) and (4), except that involve Cox. The coefficient on Cox* DE is

${ }^{93}$ We do not include noninteracted Digex and Cox variables in the regressions because they are almost but not perfectly co-linear with the year fixed effects, leading to some odd coefficients if we include them. 
positive in all four regressions, but mostly insignificant; it is marginally significant in regression (4). This is mild evidence supporting the hypothesis that Cox further contributed to the out of Delaware trend.

\section{Testing Hypothesis 2 on First-to-file}

Hypothesis 2 predicts that after the weakening of first-to-file as a basis for allocating the lead counsel role in Delaware, signalled by the $T C W$ decision in 2000 , "fast filer" plaintiff lawyers suing Delaware targets would find it more valuable to file outside Delaware, relative to one or both of our two control groups: all non-Delaware firms, and away-non-Delaware firms. This would lead to a post- $T C W$ reduction in the time to file for suits outside Delaware against Delaware targets, relative to non-Delaware targets. We might also expect any effect to be stronger for large M\&A transactions than for LBOs, because the greater number of unconsolidated suits per deal (6.3 versus 3.2), and shorter median filing time (2.5 days versus 4.0 days) suggest more intense competition to file first. ${ }^{94}$

Table 9 presents results for a test of this hypothesis. The sample is all suits outside Delaware. The regression method is OLS with year fixed effects. The dependent variable is the number of days from deal announcement to lawsuit filing. The independent variables are $\ln (\mathrm{deal}$ value), a Delaware incorporation dummy, a constant term, and a $T C W * \mathrm{DE}$ dummy variable, which equals 1 for suits filed against Delaware targets after the $T C W$ opinion on October 17, 2000, and 0 otherwise.

Regressions (1) and (2) relate to large M\&A transactions; regressions (3) and (4) to LBOs. Regressions (1) and (3) limit the sample to away incorporators, and thus use the narrower control group of away-non-Delaware firms. Regressions (2) and (4) use the entire sample, and

${ }^{94}$ In addition, there was a general view among our interviewees that many suits challenging arms-length takeovers had limited merit. Thus, there might be a higher proportion of small, "fast filer" firms bringing these suits. 
thus the broader control group of all non-Delaware firms. For the large M\&A sample, the coefficient of $T C W * \mathrm{DE}$ is negative and statistically significant in both specifications, indicating that for suits filed outside Delaware, the time to file shrank for Delaware targets after $T C W$, relative to both control groups. This is consistent with hypothesis $2 .^{95}$

[Table 9 about here]

In contrast, the coefficient of $T C W * \mathrm{DE}$ is not significant in regressions (3) and (4), which use the LBO dataset, and is negative in regression (4). We thus find no support for hypothesis 2 for LBOs.

\section{Summary}

We identified two testable hypotheses on whether specific Delaware court decisions contributed to the out-of-Delaware trend. We find support for the trend strengthening, for both large M\&A and LBO deals, around the time of the Digex fee-cut decision in 2001. This suggests a

speculation: Will the very large fee award in Southern Peru Copper send a different signal and help to bring lawsuits back to Delaware? It is far too soon to tell, but Southern Peru Copper might well have such an effect. We also find support for the $T C W$ decision weakening the firstto-file advantage encouraging fast filers to do so outside Delaware, for large M\&A transactions but not LBOs.

\section{SHOULD DELAWARE WORRY?}

The out-of-Delaware trend in where shareholder suits are filed has potential implications for Delaware's attractiveness as a venue for incorporations. We should first be clear about what the data do not tell us. We study an effect driven by unilateral choices over litigation forum made $e x$

${ }^{95}$ In unreported robustness checks, we obtain similar results if we limit to all suits outside the state of incorporation, and similar results if we use $\ln$ (days between announcement and filing) as the dependent variable. For the small number of lawsuits (see supra note Error! Bookmark not defined.) in which the suit is filed before the deal is formally announced, we treat the number of days between announcement and filing as zero. The results are robust to their exclusion or to their inclusion as negative values. 
post by plaintiffs' counsel. Selection of a forum other than Delaware indicates only that this choice is in their perceived interests. It does not indicate that the selected forum is "better" than Delaware, in the sense of cheaper, quicker, or more expert. It does not even indicate that the expected outcome is better for shareholders. Indeed, we find evidence that out-of-Delaware filing is sometimes driven, at least in large M\&A transactions, by skirmishing within the plaintiffs' bar over the lead counsel role. We also find evidence, for both large M\&A and LBO deals, consistent with plaintiffs' lawyers choosing where to file based on where they expect to receive a larger fee award. ${ }^{96}$ And the parties to merger agreements often specify Delaware when public companies are involved. ${ }^{97}$

In other words, our results do not suggest that lawsuits are filed outside Delaware because Delaware has become less competitive as a dispute resolution forum, either for contract disputes involving merger agreements or shareholder challenges to M\&A transactions.

However, the out-of-Delaware trend might be a cause, rather than an effect, of some diminution in Delaware's attractiveness as a venue for incorporation. We find two related but distinct effects: movement of lawsuits involving Delaware companies from Delaware to elsewhere; and a rise in multi-forum litigation based on common facts.

Consider first the movement of cases from Delaware to other forums. If most of the cases that Delaware loses to other forums are low-quality, nuisance cases, this could be desirable from Delaware's point of view. Low-quality suits take up at least some judicial time, that could be better allocated to more meaningful matters, and rarely generate useful precedents. If these cases are filed elsewhere, that might increase the quality of the judicial service Delaware

96 See also Cain and Davidoff (2012b).

97 Studies of forum selection clauses in merger agreements find that the parties to these agreements often specify Delaware when public companies are involved. See sources cited in note 33 supra. 
corporations could expect to receive from the Delaware courts in important cases, when they most need it. On the other hand, if Delaware loses a significant number of quality cases, this would impair the ability of its courts to develop new precedents. In the long run, this might diminish Delaware's value-added for firms and affect its market share in incorporations, its ability to charge a premium price to public companies, or both.

Delaware judges have emphasized that when lawyers do a good job and obtain a substantial recovery, they are prepared to endorse lucrative fee awards. If this were reliably true (Digex suggests that it is not always the case), and plaintiff lawyers knew the quality of their cases ex ante, then Delaware might mostly lose weaker cases. However, as the plaintiffs' lawyers we interviewed advised us, they often cannot ascertain the strength of cases very well in the early stages of litigation, prior to discovery. Thus, plaintiff lawyers will decide where to file based on expected outcomes across a range of to-be-determined case quality, and the filing of good cases in Delaware might be deterred too, perhaps nearly as much as the filing of bad ones.

While we do not study case quality within each dataset, Delaware's likely loss of some good cases is supported by our finding an out-of-Delaware trend for our LBO, judicial opinions, and option backdating datasets, all of which likely include a significant number of strong cases. LBO cases involve conflicts of interest; at least some of them are likely to lead to strong cases, and the out-of-Delaware trend is if anything stronger for LBOs than for large M\&A transactions (see Table 6). Moreover, cases that lead to written decisions, as in our judicial opinions dataset, are also likely to be relatively strong.

For our options backdating dataset, we were able to obtain at least some outcome data for 193 of the 234 suits (82\%) filed against Delaware companies. For these suits, the settlement rate 
was similar across forums, and averaged $60 \% .{ }^{98} \mathrm{We}$ were only able to obtain settlement details for 50 of these suits. The average payout was $\$ 6.36$ million for the 20 settlements in federal court; $\$ 7.84$ million for the 25 settlements in state courts other than Delaware; and $\$ 3.97$ for the five settlements in Delaware. Given the small sample sizes, the differences between these amounts are not statistically significant. But they support the view that Delaware lost some significant cases, at least in this dataset. In a companion article, we collect anecdotal evidence that Delaware is losing some important cases. ${ }^{99}$

Consider now the rise in parallel litigation. This trend is stronger for companies that incorporate outside their home state, and seems unambiguously adverse to Delaware's value added. Increasingly, if company directors want to be sued in fewer places, incorporating at home has advantages. The substance of corporate law in one's home state will usually be similar to Delaware - sometimes more management friendly, rarely less so. The decisionmakers will often be less expert, but if one is going to be sued at home anyway, one might prefer to be sued only at home, not in Delaware too.

\section{CONCLUSION}

The Delaware Chancery Court has long functioned as a de facto "national" court for U.S. corporate law. Most public companies incorporate in Delaware, and law students learning corporate law often read principally Delaware cases. The conventional wisdom until recently has been that corporate lawsuits involving Delaware companies are usually resolved in the Delaware courts. We provide consistent evidence, relying on four separate datasets, that this has changed. The general trends are as follows. First, we find a secular increase in the likelihood of

98 The settlement rate was $56 \%$ in Delaware, $57 \%$ in Federal courts and $63 \%$ in other state courts. However, suits filed in Delaware appear less likely to be dismissed than the overall average (19\% vs. 33\%) and more likely to have a motion to dismiss denied (13\% vs. 5\%). The small sample sizes mean these differences are not significant.

99 ABC Balancing Act (2012). 
litigation for both large M\&A and LBO transactions. Second, in the last several years, there has also been a higher probability that suits challenging these transactions will be filed in multiple fora.

These general trends are associated with several Delaware-specific trends. First, in both large M\&A and LBO cases, Delaware companies are receiving more suits. Some of this rise is general to all M\&A target companies, but some, especially the rise in multi-forum litigation, is either specific to or stronger for Delaware companies. Some of the trends for Delaware companies also apply to other away-incorporators (the small sample of away-non-Delaware incorporators limits our ability to distinguish Delaware trends from away-incorporator trends). Still, Delaware firms are increasingly more likely to be sued, and more likely to face multiple lawsuits, than firms incorporated in their home state. Second, there is an increasing likelihood that takeover litigation against Delaware companies will entirely bypass the Delaware courts; this trend is specific to Delaware companies, even compared only to other away incorporators.

Third, for cases involving Delaware companies, the Delaware courts are getting a smaller share of suits and writing a smaller share of publicly available written opinions. They are not receiving fewer suits, nor writing fewer opinions; rather, there are more suits and opinions outside Delaware. The decline in the likelihood that an opinion in a corporate law case will be written by the courts of the state of incorporation is greater for Delaware companies than other companies, including other away- incorporators.

We find support for two hypotheses linking the Delaware-specific effects in M\&A transactions to specific changes in practice by Delaware courts. Specifically: (1) we find support for the proposition that closer scrutiny of plaintiff attorneys' fees encouraged filing outside Delaware for both large M\&A and LBO deals; and (2) we find support for the proposition that 
that the weakening of the first-to-file custom increased the likelihood that fast-filing law firms would file large M\&A cases outside Delaware (but no similar trend for LBOs).

The social value of litigation rates this high is dubious. Perhaps a rate of litigation challenging LBOs approaching $100 \%$ can be justified as a sensible way to control agency costs in these conflict-of-interest transactions. However, it seems hard to justify this high a rate for arms-length takeovers. The social value of multi-forum litigation is also doubtful; save perhaps as a check on any tendency for the Delaware court to unduly favor defendants.

The implications of the decline in the Delaware courts' market share of cases and opinions depends on the quality of the cases which have migrated from Delaware to elsewhere. It seems likely that Delaware is losing at least some good cases - though surely along with many weak ones, especially in our large M\&A dataset. And the rise in multi-forum litigation seems likely to encourage firms to incorporate at home, if only so the directors will be sued in fewer places. It is hard to resist the conclusion that the trends present a challenge for Delaware's dominance. How strong a challenge remains to be seen. 


\section{References}

Abbott, Christy L. (2009), The Shareholder Derivative Suit as a Response to Stock Option Backdating, 53 ST. LouIS U.L.J. 593.

Armour, John, Bernard Black, Brian Cheffins and Richard Nolan (2009), Private Enforcement of Corporate Law: An Empirical Comparison of the UK and US, 6 J. EMP. LEG. STUD. 687.

Armour, John, Bernard Black and Brian Cheffins (2012), Delaware's Balancing Act, 87 IND. L.J. 1345.

Bassett, Debra Lyn (2006), The Forum Game, 84 N.C. L. REV. 333.

Bebchuck, Lucian Ayre and Assaf Hamdani (2002), Vigorous Race or Leisurely Walk: Reconsidering the Competition Over Corporate Charters, 112 YALE L.J. 553.

Berger, Carolyn and Darla Pomeroy (1992), Settlement Fever: How a Delaware Court Tackles its Cases, Bus. LAw TODAY 7.

Branson, Douglas M (1990), Indeterminacy: The Final Ingredient in an Interest Group Analysis of Corporate Law, 43 VAND. L. REV. 85.

Cain, Matthew D. and Steven M. Davidoff (2012a), Delaware's Competitive Reach, 9 J. EMPIR. LEG. STUD. 128.

-_- (2012b), A Great Game: The Dynamics of State Competition and Litigation, working paper, at http://ssrn.com/abstract=1984758.

Cary, William L. (1974), Federalism and Corporate Law: Reflections Upon Delaware, 83 YALE L.J. 663.

Chandler, William B. (2001), Awarding Counsel Fees in Class and Derivative Litigation in the Delaware Court of Chancery, working paper.

Cheffins, Brian, John Armour and Bernard Black (2012), Delaware Corporate Litigation and the Fragmentation of the Plaintiffs' Bar, 2012 COLuM. Bus. L. REV. ---

Coates, John C. IV (2012), Managing Disputes Through Contract: Evidence From M\&A, HARV. BUS. L. REV. ----

Coffee, John C. (1986), Understanding the Plaintiff's Attorney: The Implications for Economic Theory for Private Enforcement of Law Through Class and Derivative Actions, 86 COLUM. L. REV. 669.

Committee on Securities Litigation (2008), Association of the Bar of the City of New York, Coordinating Related Securities Litigation: A Position Paper.

Cornerstone Research (2010), Securities Class Actions Filings - 2009: A Year in Review.

-_-_(2012), Recent Developments in Shareholder Litigation Involving Mergers and Acquisitions.

Eisenberg, Theodore and Geoffrey Miller (2006), Ex Ante Choices of Law and Forum: An Empirical Analysis of Corporate Merger Agreements, 59 VAND. L. REV. 1975.

Erichson, Howard M. (2008), CAFA's Impact on Class Action Lawyers, 156 U. PA. L. REV. 1593. 
Erickson, Jessica (2010), Corporate Governance in the Courtroom: An Empirical Analysis, 51 WILLIAM \& MARY L. REV. 1749.

Financial Accounting Standards Board, Statement of Financial Accounting Standards (SFAS) 123 (Revised), Share-Based Payment, 2004, available at http://www.fasb.org/summary/stsum123r.shtml.

Fisch, Jill E. (2001), Aggregation, Auctions, and Other Developments in the Selection of Lead Counsel Under the PSLRA, 64(2) LAW \& CONTEMPORARY LEGAL PROBLEMS 53.

- - (2002), Lawyers on the Auction Block: Evaluating the Selection of Class Counsel by Auction, 102 Colum. L. ReV. 650.

Fried, Jesse M. (2008), Option Backdating and its Implications, 65 WASH. \& LEE L. REV. 853.

Hall, Brian J. and Kevin J. Murphy (2003), The Trouble with Stock Options, 17 J. ECON. PERSP. 49.

Jacobs, Jack B. (2009), The Reach of State Corporate Law Beyond State Borders: Reflections Upon Federalism, 84 N.Y.U. L. REV. 1149.

Johnson, Jennifer J.(2012), Securities Class Actions in State Court, U. CIN. L. REV. ---

Kahan, Marcel (2006), The Demand for Corporate Law: Statutory Flexibility, Judicial Quality, or Takeover Protection? 22 J. L. ECON. \& ORG. 340.

and Edward B. Rock (2005), Symbiotic Federalism and the Structure of Corporate Law, 58 VAND. L. REV. 1573.

Kamar, Ehud (1998), A Regulatory Competition Theory of Indeterminacy in Corporate Law 98 ColuM. L. ReV. 1908.

Kaouris, Demetrios G. (1995), Is Delaware Still a Haven for Incorporation?, 20 DeL. J. CoRP. L. 965.

Kaplan, Stanley A. (1976), Fiduciary Responsibility in the Management of the Corporation, 31 BUS. LAW. 883.

Klausner, Michael (1995), Corporations, Corporate Law, and Networks of Contracts, 81 VA. L. REV. 757.

Krishnan, C.N.V., Ronald W. Masulis, Randall S. Thomas and Robert B. Thompson (2011), Litigation in Mergers and Acquisitions, working paper.

Lebovitch, Mark, Jerry Silk and Jeremy Friedman (2011), Improving Multi-Jurisdictional Merger-Related Litigation, ABA Commercial \& Business Litigation Committee 1 (Feb. 14, 2011), available at http://apps.americanbar.org/litigation/committees/commercial/articles.html (last visited June 30, 2011) .

Lewis, Sara (2008), Transforming the 'Anywhere But Chancery' Problem Into the 'Nowhere but Chancery’ Solution, 14 STAN. J.L. BUS. \& FIN. 199.

Litvak, Kate (2012), How Much Can We Learn By Regressing Corporate Characteristics Against the State of Incorporation?, working paper, at http://ssrn.com/abstract=1990805 
Macey, Jonathan R. and Geoffrey P. Miller (1987), Toward an Interest-Group Theory of Delaware Corporate Law, 65 TEX. L. REV. 469.

Martin, Peter W. (2008), Reconfiguring Law Reports and the Concept of Precedent for a Digital Age, 53 VILL. L. REV. 1.

Micheletti, Edward B. and Jeness E. Parker (2012), Multi-Jurisdictional Litigation: Who Caused this Problem and Can it Be Fixed, 37 DEL. J. CORP. L. 1.

Miller, Geoffrey P. (1996), Overlapping Class Actions, 71 N.Y.U. L. REV. 514.

Newman, Gilbert (1969), Manufacturing Diversity Jurisdiction, 14 VILL. L. REV. 727.

Quinn, Brian M. (2012), Shareholder Lawsuits, Status Quo Bias, and Adoption of the Exclusive Forum Provision, U.C. DAVIS L. REV. ---

Ribstein, Larry E. and Erin Ann O'Hara (2008), Corporations and the Market for Law, U. ILL. L. REV. 661.

Romano, Roberta (1985), Law as Product: Some Pieces of the Incorporation Puzzle, 1 J. L. ECON. \& ORG. 225.

——_ (1991), The Shareholder Suit: Litigation Without Foundation?, 7 J.L. EcON. \& ORG. 55.

- - (1993), The Genius of American Corporate Law.

Rubenstein, William, Albert Conte \& Herbert B. Newberg (2002), Newberg on Class Actions, 4th ed.

Rydstrom, Jean F. (1970), Stay of Action in Federal Court Until Determination of Similar Action Pending in State Court, 5 A.L.R. Fed. 10.

Stevelman, Faith (2009), Regulatory Competition, Choice of Forum, and Delaware's Stake in Corporate Law, 34 DEL. J. CORP. L. 57.

Thompson, Robert B. and Randall S. Thomas (2004a), The New Look of Shareholder Litigation: Acquisition-Oriented Class Actions, 57 VAND. L. REV. 133.

- - - and - - (2004b), The Public and Private Faces of Derivative Lawsuits, 57 VAND. L. REV. 1747.

Tung, Frederick (2006), Before Competition: Origins of the Internal Affairs Doctrine 32 J. CoRP. L. 33.

Weiss, Elliott J. and Lawrence J. White (2004), File Early, Then Free Ride: How Delaware (Mis)Shapes Shareholder Class Actions, 57 VAND. L. REV. 1797.

Williams, Gregory P. (2011), Special Counsel Report, in Scully v. Nighthawk Radiology Holdings (Del. Ch, March 1).

Williams, Jane (1991), Survey of State Court Opinion Writing and Publication Practices, 83 LAW LIB. J. 21.

Zywicki, Todd J. (2006), Is Forum Shopping Corrupting America's Bankruptcy Courts?, 94 GEO. L.J. 1141. 
Table 1. Sample Description for M\&A and LBO Transactions.

Panel A: Largest 25 M\&A Transactions each year, 1994-2010.

\begin{tabular}{|c|c|c|c|c|c|c|c|c|c|}
\hline \multirow[b]{4}{*}{ Year } & \multirow{3}{*}{\multicolumn{2}{|c|}{ Deal value }} & \multicolumn{6}{|c|}{ Target state of incorporation } & \multirow[b]{4}{*}{ Obs. } \\
\hline & & & & & \multicolumn{4}{|c|}{ Not DE } & \\
\hline & & & \multicolumn{2}{|c|}{ DE } & Away. & on-DE & Ho & & \\
\hline & Mean & Median & No. & $\%$ & No. & $\%$ & No. & $\%$ & \\
\hline 1994 & $\$ 3,033$ & $\$ 1,861$ & 17 & $68 \%$ & 4 & $16 \%$ & 4 & $16 \%$ & 25 \\
\hline 1995 & $\$ 5,157$ & $\$ 3,865$ & 11 & $44 \%$ & 2 & $8 \%$ & 12 & $48 \%$ & 25 \\
\hline 1996 & $\$ 8,063$ & $\$ 4,747$ & 15 & $60 \%$ & 2 & $8 \%$ & 8 & $32 \%$ & 25 \\
\hline 1997 & $\$ 8,189$ & $\$ 5,745$ & 13 & $52 \%$ & 3 & $12 \%$ & 9 & $36 \%$ & 25 \\
\hline 1998 & $\$ 31,096$ & $\$ 18,117$ & 17 & $68 \%$ & 3 & $12 \%$ & 5 & $20 \%$ & 25 \\
\hline 1999 & $\$ 25,187$ & $\$ 13,968$ & 17 & $68 \%$ & 2 & $8 \%$ & 6 & $24 \%$ & 25 \\
\hline 2000 & $\$ 25,235$ & $\$ 15,253$ & 20 & $80 \%$ & 4 & $16 \%$ & 1 & $4 \%$ & 25 \\
\hline 2001 & $\$ 8,941$ & $\$ 5,608$ & 15 & $60 \%$ & 5 & $20 \%$ & 5 & $20 \%$ & 25 \\
\hline 2002 & $\$ 5,122$ & $\$ 1,320$ & 19 & $76 \%$ & 4 & $16 \%$ & 2 & $8 \%$ & 25 \\
\hline 2003 & $\$ 7,016$ & $\$ 3,165$ & 17 & $68 \%$ & 3 & $12 \%$ & 5 & $20 \%$ & 25 \\
\hline 2004 & $\$ 11,811$ & $\$ 5,846$ & 16 & $64 \%$ & 4 & $16 \%$ & 5 & $20 \%$ & 25 \\
\hline 2005 & $\$ 14,264$ & $\$ 7,869$ & 17 & $68 \%$ & 2 & $8 \%$ & 6 & $24 \%$ & 25 \\
\hline 2006 & $\$ 14,033$ & $\$ 8,710$ & 14 & $56 \%$ & 5 & $20 \%$ & 6 & $24 \%$ & 25 \\
\hline 2007 & $\$ 8,339$ & $\$ 6,944$ & 16 & $64 \%$ & 5 & $20 \%$ & 4 & $16 \%$ & 25 \\
\hline 2008 & $\$ 12,485$ & $\$ 7,555$ & 20 & $80 \%$ & 0 & $0 \%$ & 5 & $20 \%$ & 25 \\
\hline 2009 & $\$ 11,543$ & $\$ 4,279$ & 20 & $80 \%$ & 2 & $8 \%$ & 3 & $12 \%$ & 25 \\
\hline 2010 & $\$ 8,508$ & $\$ 4,016$ & 18 & $72 \%$ & 3 & $12 \%$ & 4 & $16 \%$ & 25 \\
\hline All & $\$ 12,237$ & $\$ 6,867$ & 282 & $66 \%$ & 53 & $13 \%$ & 90 & $21 \%$ & 425 \\
\hline
\end{tabular}

Panel B: Leveraged buyouts (LBOs), 1995-2010.

\begin{tabular}{|c|c|c|c|c|c|c|c|c|c|}
\hline \multirow[b]{4}{*}{ Year } & \multirow{3}{*}{\multicolumn{2}{|c|}{ Deal value }} & \multicolumn{6}{|c|}{ Target state of incorporation } & \multirow[b]{4}{*}{ Obs. } \\
\hline & & & & & \multicolumn{4}{|c|}{ Not DE } & \\
\hline & & & \multicolumn{2}{|c|}{ DE } & Away & Dn-DE & & & \\
\hline & Mean & Median & No. & $\%$ & No. & $\%$ & No. & $\%$ & \\
\hline 1995 & $\$ 735$ & $\$ 313$ & 4 & $80 \%$ & 1 & $20 \%$ & 0 & $0 \%$ & 5 \\
\hline 1996 & $\$ 371$ & $\$ 78$ & 11 & $73 \%$ & 0 & $0 \%$ & 4 & $27 \%$ & 15 \\
\hline 1997 & $\$ 424$ & $\$ 202$ & 23 & $68 \%$ & 4 & $12 \%$ & 7 & $21 \%$ & 34 \\
\hline 1998 & $\$ 313$ & $\$ 242$ & 19 & $61 \%$ & 2 & $6 \%$ & 10 & $32 \%$ & 31 \\
\hline 1999 & $\$ 376$ & $\$ 239$ & 28 & $61 \%$ & 2 & $4 \%$ & 16 & $35 \%$ & 46 \\
\hline 2000 & $\$ 316$ & $\$ 108$ & 38 & $68 \%$ & 4 & $7 \%$ & 14 & $25 \%$ & 56 \\
\hline 2001 & $\$ 196$ & $\$ 40$ & 15 & $58 \%$ & 2 & $8 \%$ & 9 & $35 \%$ & 26 \\
\hline 2002 & $\$ 315$ & $\$ 39$ & 17 & $77 \%$ & 1 & $5 \%$ & 4 & $18 \%$ & 22 \\
\hline 2003 & $\$ 104$ & $\$ 32$ & 14 & $64 \%$ & 1 & $5 \%$ & 7 & $32 \%$ & 22 \\
\hline 2004 & $\$ 1,209$ & $\$ 392$ & 21 & $81 \%$ & 1 & $4 \%$ & 4 & $15 \%$ & 26 \\
\hline 2005 & $\$ 1,899$ & $\$ 717$ & 22 & $59 \%$ & 3 & $8 \%$ & 12 & $32 \%$ & 37 \\
\hline 2006 & $\$ 4,652$ & $\$ 1,299$ & 37 & $55 \%$ & 10 & $15 \%$ & 20 & $30 \%$ & 67 \\
\hline 2007 & $\$ 4,642$ & $\$ 1,360$ & 32 & $59 \%$ & 2 & $4 \%$ & 20 & $37 \%$ & 54 \\
\hline 2008 & $\$ 561$ & $\$ 247$ & 8 & $47 \%$ & 2 & $12 \%$ & 7 & $41 \%$ & 17 \\
\hline 2009 & $\$ 452$ & $\$ 152$ & 18 & $69 \%$ & 2 & $8 \%$ & 6 & $23 \%$ & 26 \\
\hline 2010 & $\$ 1,177$ & $\$ 637$ & 32 & $89 \%$ & 0 & $0 \%$ & 4 & $11 \%$ & 36 \\
\hline All & $\$ 1,584$ & $\$ 271$ & 339 & $65 \%$ & 37 & $7 \%$ & 144 & $28 \%$ & 520 \\
\hline
\end{tabular}

NotE: Average annual deal values (\$m, not inflation-adjusted) and state of incorporation of targets for largest 25 M\&A transactions (mergers and tender offers) by dollar value (Panel A), and LBO transactions (Panel B). Deal data is from SDC Platinum and reflects completed transactions involving US public target companies. State of incorporation data is from EDGAR. For firms incorporated other than in Delaware, "Away-non-DE" indicates targets incorporated outside home state but not in Delaware. "Home" indicates targets incorporated in their home states (if other than Delaware). 
Table 2. Descriptive Statistics for Lawsuits in Large M\&A and LBO Datasets

\begin{tabular}{|c|c|c|c|c|c|c|c|c|c|c|c|}
\hline & & \multicolumn{2}{|c|}{ Litigated } & \multicolumn{3}{|c|}{2 or more suits } & \multicolumn{4}{|c|}{ Suit type } & \multirow{2}{*}{$\begin{array}{l}\text { Median days to } \\
\text { file suit after } \\
\text { deal announced }\end{array}$} \\
\hline & $\begin{array}{l}\text { No. of } \\
\text { Deals }\end{array}$ & $\begin{array}{r}\text { No. of } \\
\text { suits } \\
\end{array}$ & $\begin{array}{l}\% \text { of } \\
\text { deals }\end{array}$ & $\begin{array}{r}\text { No. of } \\
\text { deals }\end{array}$ & $\begin{array}{c}\% \text { of } \\
\text { litigated }\end{array}$ & $\begin{array}{l}\% \text { of } \\
\text { deals }\end{array}$ & $\begin{array}{l}\text { No. of } \\
\text { Suits }\end{array}$ & $\begin{array}{c}\text { Class } \\
\text { action }\end{array}$ & $\begin{array}{l}\text { Other } \\
\text { direct }\end{array}$ & Derivative & \\
\hline \multicolumn{12}{|l|}{ Large M\&A, 1994-2010 } \\
\hline $\mathrm{DE}$ & 282 & 135 & $47.9 \%$ & 65 & $48.1 \%$ & $23.0 \%$ & 231 & 210 & 12 & 24 & 2.5 \\
\hline Away-non-DE & 53 & 22 & $41.5 \%$ & 12 & $54.5 \%$ & $22.6 \%$ & 38 & 36 & 2 & 2 & 7 \\
\hline Home & 90 & 48 & $53.3 \%$ & 15 & $31.3 \%$ & $16.7 \%$ & 67 & 58 & 2 & 6 & 3 \\
\hline Totals & 425 & 205 & $48.2 \%$ & 92 & $44.9 \%$ & $21.6 \%$ & 336 & 304 & 16 & 32 & 3 \\
\hline \multicolumn{12}{|l|}{ LBOs, 1995-2010 } \\
\hline $\mathrm{DE}$ & 339 & 176 & $51.9 \%$ & 58 & $33.0 \%$ & $17.1 \%$ & 241 & 236 & 3 & 9 & 4 \\
\hline Away-non-DE & 37 & 13 & $35.1 \%$ & 6 & $46.2 \%$ & $16.2 \%$ & 22 & 22 & 0 & 2 & 3 \\
\hline Home & 144 & 54 & $37.5 \%$ & 9 & $16.7 \%$ & $6.3 \%$ & 64 & 61 & 0 & 7 & 4 \\
\hline Totals & 520 & 243 & $46.7 \%$ & 73 & $30.0 \%$ & $14.0 \%$ & 327 & 319 & 3 & 18 & 4 \\
\hline
\end{tabular}

NOTE: Number, type of lawsuits, and time to file suit in relation to target companies in largest $25 \mathrm{M} \& \mathrm{~A}$ transactions (mergers and tender offers) by dollar value and all LBO transactions in SDC Platinum database. Data on lawsuits are obtained from EDGAR. We treat as a single consolidated suit all suits in the same jurisdiction which could have been consolidated. Totals for suit types exceed total number of suits because some suits involve both direct and derivative claims. 
Table 3. Sample description for judicial opinions dataset, 1995-2009

\begin{tabular}{|c|c|c|c|c|c|c|c|c|c|c|c|c|c|c|c|}
\hline \multirow{3}{*}{ Year } & \multirow{3}{*}{$\begin{array}{c}\text { No. } \\
\text { of } \\
\text { cases }\end{array}$} & \multicolumn{6}{|c|}{ State of incorporation } & \multirow{2}{*}{\multicolumn{2}{|c|}{ Takeover case }} & \multicolumn{6}{|c|}{ Suit type } \\
\hline & & \multicolumn{2}{|c|}{ Delaware } & \multicolumn{2}{|c|}{$\begin{array}{c}\text { Away-non- } \\
\text { DE }\end{array}$} & \multicolumn{2}{|c|}{ Home state } & & & \multicolumn{2}{|c|}{ Class action } & \multicolumn{2}{|c|}{ Direct action } & \multicolumn{2}{|c|}{$\begin{array}{l}\text { Derivative } \\
\text { suit }\end{array}$} \\
\hline & & No.\# & $\%$ & No. & $\%$ & No. & $\%$ & No. & No. & No. & $\%$ & No. & No. & No. & $\%$ \\
\hline 1995 & 14 & 12 & 85.7 & 0 & 0.0 & & 2 & 11 & 11 & 6 & 42.9 & 0 & 0.0 & 11 & $\overline{78.6}$ \\
\hline 1996 & 28 & 24 & 85.7 & 2 & 7.1 & 2 & 2 & 14 & 14 & 6 & 21.4 & 8 & 28.6 & 14 & 50.0 \\
\hline 1997 & 14 & 10 & 71.4 & 1 & 7.1 & 3 & 3 & 10 & 10 & 1 & 7.7 & 2 & 15.4 & 10 & 76.9 \\
\hline 1998 & 28 & 17 & 60.7 & 3 & 10.7 & 8 & 8 & 18 & 18 & 4 & 14.8 & 6 & 22.2 & 18 & 66.7 \\
\hline 1999 & 26 & 19 & 73.1 & 2 & 7.7 & 5 & 5 & 15 & 15 & 11 & 42.3 & 1 & 3.8 & 15 & 57.7 \\
\hline 2000 & 47 & 40 & 85.1 & 3 & 6.4 & 4 & 4 & 18 & 18 & 18 & 38.3 & 14 & 29.8 & 18 & 38.3 \\
\hline 2001 & 37 & 32 & 86.5 & 2 & 5.4 & 3 & 3 & 14 & 14 & 15 & 40.5 & 10 & 27.0 & 14 & 37.8 \\
\hline 2002 & 34 & 30 & 88.2 & 2 & 5.9 & 2 & 2 & 16 & 16 & 14 & 41.2 & 7 & 20.6 & 16 & 47.1 \\
\hline 2003 & 67 & 47 & 70.1 & 4 & 6.0 & 16 & 16 & 41 & 41 & 24 & 36.4 & 9 & 13.6 & 41 & 62.1 \\
\hline 2004 & 49 & 38 & 77.6 & 3 & 6.1 & 8 & 8 & 31 & 31 & 11 & 22.4 & 10 & 20.4 & 31 & 63.3 \\
\hline 2005 & 63 & 46 & 73.0 & 8 & 12.7 & 9 & 9 & 37 & 37 & 17 & 27.9 & 9 & 14.8 & 37 & 60.7 \\
\hline 2006 & 69 & 55 & 79.7 & 4 & 5.8 & 10 & 10 & 57 & 57 & 12 & 17.4 & 8 & 11.6 & 57 & 82.6 \\
\hline 2007 & 96 & 69 & 71.9 & 9 & 9.4 & 18 & 18 & 65 & 65 & 20 & 20.8 & 13 & 13.5 & 65 & 67.7 \\
\hline 2008 & 72 & 53 & 73.6 & 4 & 5.6 & 15 & 15 & 48 & 48 & 14 & 19.4 & 10 & 13.9 & 48 & 66.7 \\
\hline 2009 & 60 & 48 & 80.0 & 3 & 5.0 & 9 & 9 & 44 & 44 & 19 & 31.7 & 1 & 1.7 & 44 & 73.3 \\
\hline All & 704 & 540 & 76.7 & 50 & 7.1 & 114 & 114 & 439 & 439 & 192 & 27.5 & 108 & 15.5 & 439 & 62.8 \\
\hline
\end{tabular}

NOTE: Number and type of lawsuits in judicial opinions dataset. Opinions dataset comprises corporate law cases brought in any US state or federal court in relation to US public companies and naming one or more directors as defendants which produced one or more publicly-available written judicial opinion between 1995 and 2009 . Totals for suit types exceed total number of suits because some suits involve both direct and derivative claims. 
Table 4: Likelihood of Takeover Litigation

\begin{tabular}{|c|c|c|c|c|c|c|c|c|c|c|}
\hline dataset & $\begin{array}{c}(1) \\
\text { Large } \\
\text { M\&A }\end{array}$ & $\begin{array}{c}(2) \\
\text { Large } \\
\text { M\&A }\end{array}$ & $\begin{array}{c}(3) \\
\text { Large } \\
\text { M\&A }\end{array}$ & $\begin{array}{c}(4) \\
\text { Large } \\
\text { M\&A }\end{array}$ & $\begin{array}{c}(5) \\
\text { Large } \\
\text { M\&A }\end{array}$ & $\begin{array}{c}(6) \\
\text { LBOs }\end{array}$ & $\begin{array}{c}(7) \\
\text { LBOs }\end{array}$ & $\begin{array}{c}(8) \\
\text { LBOs }\end{array}$ & $\begin{array}{c}(9) \\
\text { LBOs }\end{array}$ & $\begin{array}{l}(10) \\
\text { LBOs }\end{array}$ \\
\hline sample & $\mathrm{DE}$ & Non-DE & All & All & Away & $\mathrm{DE}$ & Non-DE & All & All & Away \\
\hline time trend & $\begin{array}{c}0.0290^{* * * * *} \\
(4.58)\end{array}$ & $\begin{array}{c}0.0290^{* * * * *} \\
(3.20)\end{array}$ & $\begin{array}{c}\mathrm{O.0289}^{* * 3 * *} \\
(\mathbf{5 . 5 8})\end{array}$ & $\begin{array}{c}\mathbf{0 . 0 3 5 6}^{* * * *} \\
(\mathbf{3 . 1 5})\end{array}$ & $\begin{array}{c}0.0294^{* * * * *} \\
(4.62)\end{array}$ & $\begin{array}{c}0.04411^{* * 3 *} \\
(5.85)\end{array}$ & $\begin{array}{l}0.0137 \\
(1.27)\end{array}$ & $\begin{array}{c}0.0356^{3 * * *} \\
(5.64)\end{array}$ & $\begin{array}{c}0.0140 \\
(1.14)\end{array}$ & $\begin{array}{c}0.0445^{* * * *} \\
(5.88)\end{array}$ \\
\hline $\ln$ (value) & $\begin{array}{c}0.0410 \\
(1.41)\end{array}$ & $\begin{array}{c}0.0224 \\
(0.44)\end{array}$ & $\begin{array}{c}0.0363 \\
(1.45)\end{array}$ & $\begin{array}{c}0.0352 \\
(1.40)\end{array}$ & $\begin{array}{c}0.0220 \\
(0.83)\end{array}$ & $\begin{array}{c}0.0882^{* * * *} \\
(5.36)\end{array}$ & $\begin{array}{c}0.107^{* * * *} \\
(4.96)\end{array}$ & $\begin{array}{c}0.0976^{* * *} \\
(7.26)\end{array}$ & $\begin{array}{c}0.0983^{* * *} \\
(7.27)\end{array}$ & $\begin{array}{c}0.0893^{* * *} \\
(5.74)\end{array}$ \\
\hline Away-non-DE incorp & & $\begin{array}{l}-0.153^{*} \\
(-1.75)\end{array}$ & $\begin{array}{l}-0.152^{*} \\
(-1.82)\end{array}$ & $\begin{array}{c}-0.00716 \\
(-0.04)\end{array}$ & $\begin{array}{c}0.0490 \\
(0.32)\end{array}$ & & $\begin{array}{c}0.00788 \\
(0.08)\end{array}$ & $\begin{array}{c}-0.00414 \\
(-0.04)\end{array}$ & $\begin{array}{l}-0.110 \\
(-0.40)\end{array}$ & $\begin{array}{l}-0.0136 \\
(-0.05)\end{array}$ \\
\hline DE incorp & & & $\begin{array}{l}-0.103 \\
(-1.64)\end{array}$ & $\begin{array}{r}-0.0597 \\
(-0.54)\end{array}$ & & & & $\begin{array}{c}0.152^{* * * *} \\
(2.75)\end{array}$ & $\begin{array}{l}-0.0902 \\
(-0.71)\end{array}$ & \\
\hline DE incorp * time & & & & $\begin{array}{c}-0.00649 \\
(-0.50)\end{array}$ & & & & & $\begin{array}{c}0.0300^{* *} \\
(2.10)\end{array}$ & \\
\hline $\begin{array}{l}\text { Away-non- DE * } \\
\text { time }\end{array}$ & & & & $\begin{array}{c}-0.0196 \\
(-1.04) \\
\end{array}$ & $\begin{array}{r}-0.0134 \\
(-0.82)\end{array}$ & & & & $\begin{array}{r}0.0137 \\
(0.45) \\
\end{array}$ & $\begin{array}{r}-0.0167 \\
(-0.59)\end{array}$ \\
\hline $\begin{array}{l}\text { Pseudo } R^{2} \\
\text { Observations }\end{array}$ & $\begin{array}{c}0.062 \\
282\end{array}$ & $\begin{array}{c}0.067 \\
143\end{array}$ & $\begin{array}{c}0.064 \\
425\end{array}$ & $\begin{array}{c}0.065 \\
425\end{array}$ & $\begin{array}{c}0.055 \\
332\end{array}$ & $\begin{array}{c}0.209 \\
320\end{array}$ & $\begin{array}{c}0.167 \\
167\end{array}$ & $\begin{array}{c}0.201 \\
487\end{array}$ & $\begin{array}{c}0.208 \\
487\end{array}$ & $\begin{array}{c}0.210 \\
350\end{array}$ \\
\hline
\end{tabular}

NOTE: Large M\&A sample is 25 largest M\&A transactions (mergers and tender offers) by dollar value in each year, for 1994-2010. LBO sample is leveraged buyouts over 1995-2010. Probit models of the likelihood that a transaction will attract a lawsuit. We treat as a single consolidated suit all suits in the same jurisdiction which could have been consolidated. Table shows marginal effects, holding other variables at their median values. Heteroskedasticity consistent $t$ statistics are parentheses. Significant results in boldface. ${ }^{*} p<0.1,{ }^{* *} p<0.05,{ }^{* * *} p<0.01$. 
Table 5. Likelihood of takeover litigation in two or more jurisdictions

\begin{tabular}{|c|c|c|c|c|c|c|c|c|c|c|}
\hline dataset & $\begin{array}{c}(1) \\
\text { Large } \\
\text { M\&A }\end{array}$ & $\begin{array}{c}(2) \\
\text { Large } \\
\text { M\&A }\end{array}$ & $\begin{array}{c}(3) \\
\text { Large } \\
\text { M\&A }\end{array}$ & $\begin{array}{c}(4) \\
\text { Large } \\
\text { M\&A }\end{array}$ & $\begin{array}{c}(5) \\
\text { Large } \\
\text { M\&A }\end{array}$ & $\begin{array}{c}(6) \\
\text { LBOs }\end{array}$ & $\begin{array}{c}(7) \\
\text { LBOs }\end{array}$ & $\begin{array}{c}(8) \\
\text { LBOs }\end{array}$ & $\begin{array}{c}(9) \\
\text { LBOs }\end{array}$ & $\begin{array}{l}(10) \\
\text { LBOs }\end{array}$ \\
\hline sample & $\mathrm{DE}$ & Non-DE & All & All & Away & $\mathrm{DE}$ & Non-DE & All & All & Away \\
\hline time trend & $\begin{array}{c}0.0272^{* * * *} \\
(\mathbf{5 . 3 1})\end{array}$ & $\begin{array}{c}0.00628 \\
(0.96)\end{array}$ & $\begin{array}{c}0.0197^{*, * 3 *} \\
(4.90)\end{array}$ & $\begin{array}{c}0.00347 \\
(0.40)\end{array}$ & $\begin{array}{c}\mathbf{0 . 0 2 7 6}^{* * * *} \\
(\mathbf{5 . 3 0})\end{array}$ & $\begin{array}{c}0.0225^{* * * * *} \\
(4.67)\end{array}$ & $\begin{array}{c}0.00294 \\
(1.09)\end{array}$ & $\begin{array}{c}0^{0.0148} 8^{* * * * *} \\
(4.50)\end{array}$ & $\begin{array}{c}0.0204^{* * *} \\
(2.24)\end{array}$ & $\begin{array}{c}0.0215^{* * * 3} \\
(4.58)\end{array}$ \\
\hline $\ln$ (value) & $\begin{array}{l}0.0167 \\
(0.69)\end{array}$ & $\begin{array}{c}0.00532 \\
(0.14)\end{array}$ & $\begin{array}{c}0.0105 \\
(0.52)\end{array}$ & $\begin{array}{c}0.0140 \\
(0.69)\end{array}$ & $\begin{array}{c}0.00406 \\
(0.18)\end{array}$ & $\begin{array}{c}0.0469^{* * * *} \\
(4.57)\end{array}$ & $\begin{array}{c}0.0207^{* *} \\
(2.09)\end{array}$ & $\begin{array}{c}0.0414^{* * * *} \\
(6.04)\end{array}$ & $\begin{array}{c}0.0392^{* * * *} \\
(\mathbf{5 . 3 0})\end{array}$ & $\begin{array}{c}0.0523^{* * *} \\
(\mathbf{5 . 4 7})\end{array}$ \\
\hline $\begin{array}{l}\text { Away-non-DE } \\
\text { incorp }\end{array}$ & & $\begin{array}{c}0.0531 \\
(0.76)\end{array}$ & $\begin{array}{c}0.0473 \\
(0.61)\end{array}$ & $\begin{array}{c}-0.00666 \\
(-0.05)\end{array}$ & $\begin{array}{l}0.168 \\
(1.10)\end{array}$ & & $\begin{array}{c}0.0622 \\
(1.28)\end{array}$ & $\begin{array}{l}0.167 \\
(1.60)\end{array}$ & $\begin{array}{c}0.753^{* *} \\
(2.49)\end{array}$ & $\begin{array}{l}0.421 \\
(1.43)\end{array}$ \\
\hline DE incorp & & & $\begin{array}{c}0.0324 \\
(0.65)\end{array}$ & $\begin{array}{l}-0.165 \\
(-1.57)\end{array}$ & & & & $\begin{array}{c}0.0824^{* * * *} \\
(3.33)\end{array}$ & $\begin{array}{l}0.126 \\
(1.53)\end{array}$ & \\
\hline $\mathrm{DE} *$ time trend & & & & $\begin{array}{c}\mathbf{0 . 0 2 3 1}{ }^{* *} \\
(2.31)\end{array}$ & & & & & $\begin{array}{c}-0.00603 \\
(-0.57)\end{array}$ & \\
\hline $\begin{array}{l}\text { Away-non-DE * } \\
\text { time }\end{array}$ & & & & $\begin{array}{c}0.00780 \\
(0.55) \\
\end{array}$ & $\begin{array}{c}-0.0159 \\
(-1.24) \\
\end{array}$ & & & & $\begin{array}{c}-0.0248^{*} \\
(-1.77) \\
\end{array}$ & $\begin{array}{c}-0.0269^{*} \\
(-1.66) \\
\end{array}$ \\
\hline Pseudo $R^{2}$ & 0.098 & 0.013 & 0.060 & 0.074 & 0.085 & 0.213 & 0.392 & 0.262 & 0.269 & 0.232 \\
\hline Observations & 282 & 143 & 425 & 425 & 332 & 320 & 167 & 487 & 487 & 350 \\
\hline
\end{tabular}

NOTE: Large M\&A sample is 25 largest M\&A transactions (mergers and tender offers) by dollar value in each year, for 1994-2010. LBO sample is leveraged buyouts over 1995-2010. Probit models of the likelihood that a transaction will attract suits in two or more jurisdictions. We treat as consolidated all suits which could be consolidated.

Table shows marginal effects, holding other variables at their median values. Heteroskedasticity consistent $t$ statistics are parentheses. Significant results in boldface. . ${ }^{*} p<$ $0.1,{ }^{* *} p<0.05,{ }^{* * * *} p<0.01$. 
Table 6. Likelihood of takeover litigation bypassing state of incorporation

\begin{tabular}{|c|c|c|c|c|c|c|c|c|c|c|}
\hline dataset & $\begin{array}{c}(1) \\
\text { Large } \\
\text { M\&A } \\
\end{array}$ & $\begin{array}{c}(2) \\
\text { Large } \\
\text { M\&A } \\
\end{array}$ & $\begin{array}{c}(3) \\
\text { Large } \\
\text { M\&A } \\
\end{array}$ & $\begin{array}{c}(4) \\
\text { Large } \\
\text { M\&A } \\
\end{array}$ & $\begin{array}{c}(5) \\
\text { Large } \\
\text { M\&A } \\
\end{array}$ & $\begin{array}{c}\text { (6) } \\
\text { LBOs }\end{array}$ & $\begin{array}{c}(7) \\
\text { LBOs }\end{array}$ & $\begin{array}{c}(8) \\
\text { LBOs }\end{array}$ & $\begin{array}{c}(9) \\
\text { LBOs }\end{array}$ & $\begin{array}{c}\text { (10) } \\
\text { LBOs }\end{array}$ \\
\hline sample & $\mathrm{DE}$ & Non-DE & All & All & Away & $\mathrm{DE}$ & Non-DE & All & All & Away \\
\hline time trend & $\begin{array}{c}\mathbf{0 . 0 2 0 2}^{* 3 *} \\
(5.20)\end{array}$ & $\begin{array}{c}-0.00192 \\
(-0.48)\end{array}$ & 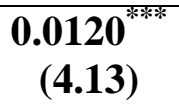 & $\begin{array}{c}-0.00711 \\
(-0.79)\end{array}$ & $\begin{array}{c}0^{0.0205}{ }^{* 3 *} \\
(5.11)\end{array}$ & $\begin{array}{c}\mathbf{0 . 0 2 5 9}^{* 3 * * 3} \\
(5.11)\end{array}$ & $\begin{array}{c}-0.000349 \\
(-0.16)\end{array}$ & $\begin{array}{c}\mathbf{0 . 0 1 2 8}^{(3.93)} \\
(\mathbf{3 . 9 3})\end{array}$ & $\begin{array}{c}0.00989 \\
(0.62)\end{array}$ & $\begin{array}{c}\mathbf{0 . 0 2 5 8}^{* 3 *} \\
(5.07)\end{array}$ \\
\hline $\ln$ (value) & $\begin{array}{c}0.0249 \\
(1.37)\end{array}$ & $\begin{array}{c}0.00963 \\
(0.45)\end{array}$ & $\begin{array}{c}0.0184 \\
(1.30)\end{array}$ & $\begin{array}{c}0.0201 \\
(1.46)\end{array}$ & $\begin{array}{c}0.0203 \\
(1.18)\end{array}$ & $\begin{array}{c}0.0303^{* * * *} \\
(2.88)\end{array}$ & $\begin{array}{c}0.00401 \\
(1.08)\end{array}$ & $\begin{array}{c}0.0163^{* * * *} \\
(2.90)\end{array}$ & $\begin{array}{c}0.0166^{* * * *} \\
(2.63)\end{array}$ & $\begin{array}{c}0.0312^{* * *} \\
(3.17)\end{array}$ \\
\hline Away-non-DE incorp & & $\begin{array}{c}0.0818^{*} \\
(1.71)\end{array}$ & $\begin{array}{l}0.123 \\
(1.39)\end{array}$ & $\begin{array}{c}0.0544 \\
(0.42)\end{array}$ & $\begin{array}{l}0.242 \\
(1.41)\end{array}$ & & $\begin{array}{l}0.136^{* * *} \\
(2.15)\end{array}$ & $\begin{array}{c}0.428^{* * * *} \\
(2.68)\end{array}$ & $\begin{array}{l}0.796^{* *} \\
(2.09)\end{array}$ & $\begin{array}{l}0.498^{*} \\
(1.92)\end{array}$ \\
\hline DE incorp & & & $\begin{array}{c}0.0881 \\
(2.61)\end{array}$ & $\begin{array}{l}-0.114 \\
(-1.12)\end{array}$ & & & & $\begin{array}{c}0.157^{* * * *} \\
(5.91)\end{array}$ & $\begin{array}{l}0.121 \\
(0.98)\end{array}$ & \\
\hline DE incorp $*$ time & & & & $\begin{array}{c}0.0241^{* * *} \\
(2.58)\end{array}$ & & & & & $\begin{array}{c}0.00466 \\
(0.25)\end{array}$ & \\
\hline Away-non-DE $*$ time & & & & $\begin{array}{c}0.00771 \\
(0.65)\end{array}$ & $\begin{array}{r}-0.0198^{*} \\
(-1.96)\end{array}$ & & & & $\begin{array}{c}-0.0168 \\
(-0.95)\end{array}$ & $\begin{array}{c}-0.03866^{* *} \\
(-2.20) \\
\end{array}$ \\
\hline Pseudo $R^{2}$ & 0.117 & 0.058 & 0.092 & 0.123 & 0.100 & 0.161 & 0.265 & 0.220 & 0.232 & 0.153 \\
\hline Observations & 282 & 143 & 425 & 425 & 332 & 320 & 167 & 487 & 487 & 350 \\
\hline
\end{tabular}

NotE: Large M\&A sample is 25 largest M\&A transactions (mergers and tender offers) by dollar value in each year, for 1994-2010. LBO sample is leveraged buyouts over 1995-2010. Probit models of the likelihood that a transaction attracts litigation solely outside state of incorporation. Table shows marginal effects, holding other variables at their median values. We treat as a single consolidated suit all suits in the same jurisdiction which could have been consolidated. Heteroskedasticity consistent $t$ statistics are parentheses. Significant results in boldface. ${ }^{*} p<0.1,{ }^{* *} p<0.05,{ }^{* * *} p<0.01$. 
Table 7. Likelihood of written opinion in corporate law case being by courts other than incorporation state

\begin{tabular}{|c|c|c|c|c|c|}
\hline & (1) & (2) & (3) & (4) & (5) \\
\hline sample & $\mathrm{DE}$ & Non DE & All & All & Away \\
\hline time trend & $\begin{array}{c}0.04266^{* * * *} \\
(6.83)\end{array}$ & $\begin{array}{c}-0.00440 \\
(-0.44)\end{array}$ & $\begin{array}{c}0.0320 \\
(6.05)\end{array}$ & $\begin{array}{c}-0.00226 \\
(-0.17)\end{array}$ & $\begin{array}{c}\mathrm{O.0422}^{* * * * *} \\
(6.86)\end{array}$ \\
\hline federal cases residual & $\begin{array}{c}0.301 \mathrm{e}-06 \\
(0.13)\end{array}$ & $\begin{array}{c}0.337 \mathrm{e}-05 \\
(0.93)\end{array}$ & $\begin{array}{c}0.111 \mathrm{e}-05 \\
(0.55)\end{array}$ & $\begin{array}{c}0.116 \mathrm{e}-05 \\
\quad(0.57)\end{array}$ & $\begin{array}{c}0.168 \mathrm{e}-06 \\
(0.07)\end{array}$ \\
\hline Away-non-DE incorp & & & $\begin{array}{c}0.204^{* * * *} \\
(2.69)\end{array}$ & $\begin{array}{l}0.174 \\
(0.81)\end{array}$ & $\begin{array}{c}0.460^{* * *} \\
(7.94)\end{array}$ \\
\hline DE incorp & & & $\begin{array}{c}-0.150^{* * * *} \\
(-3.11)\end{array}$ & $\begin{array}{c}-0.438 \\
(-5.54)\end{array}$ & \\
\hline DE * time & & & & $\begin{array}{c}\mathbf{0 . 0 4 3 1}^{\text {**** }} \\
(3.09)\end{array}$ & \\
\hline Away-non-DE $*$ time & & & & $\begin{array}{c}0.00272 \\
(0.10)\end{array}$ & $\begin{array}{c}-0.0408^{*} \\
(-1.65)\end{array}$ \\
\hline Pseudo $R^{2}$ & 0.075 & 0.005 & 0.077 & 0.089 & 0.096 \\
\hline Observations & 540 & 164 & 704 & 704 & 590 \\
\hline
\end{tabular}

NOTE: Sample is corporate law cases against directors of public companies generating one or more publicly available written opinions, over 1995-2009. Probit models of the likelihood that an opinion will be written by a court other than the courts of the state of incorporation. Table shows marginal effects, holding other variables at their median values. We treat as a single consolidated suit all suits in the same jurisdiction which could have been consolidated. "Federal cases residual" is the residual term from regressing the annual number of federal civil opinions reported in Westlaw on time trend plus constant. Heteroskedasticity consistent $t$ statistics are parentheses. Significant results in boldface. ${ }^{*} p<0.1,{ }^{* *} p<0.05,{ }^{* * *} p<0.01$. 
Table 8. Did Delaware decisions in Digex and Cox Communications affect likelihood of takeover litigation bypassing Delaware?

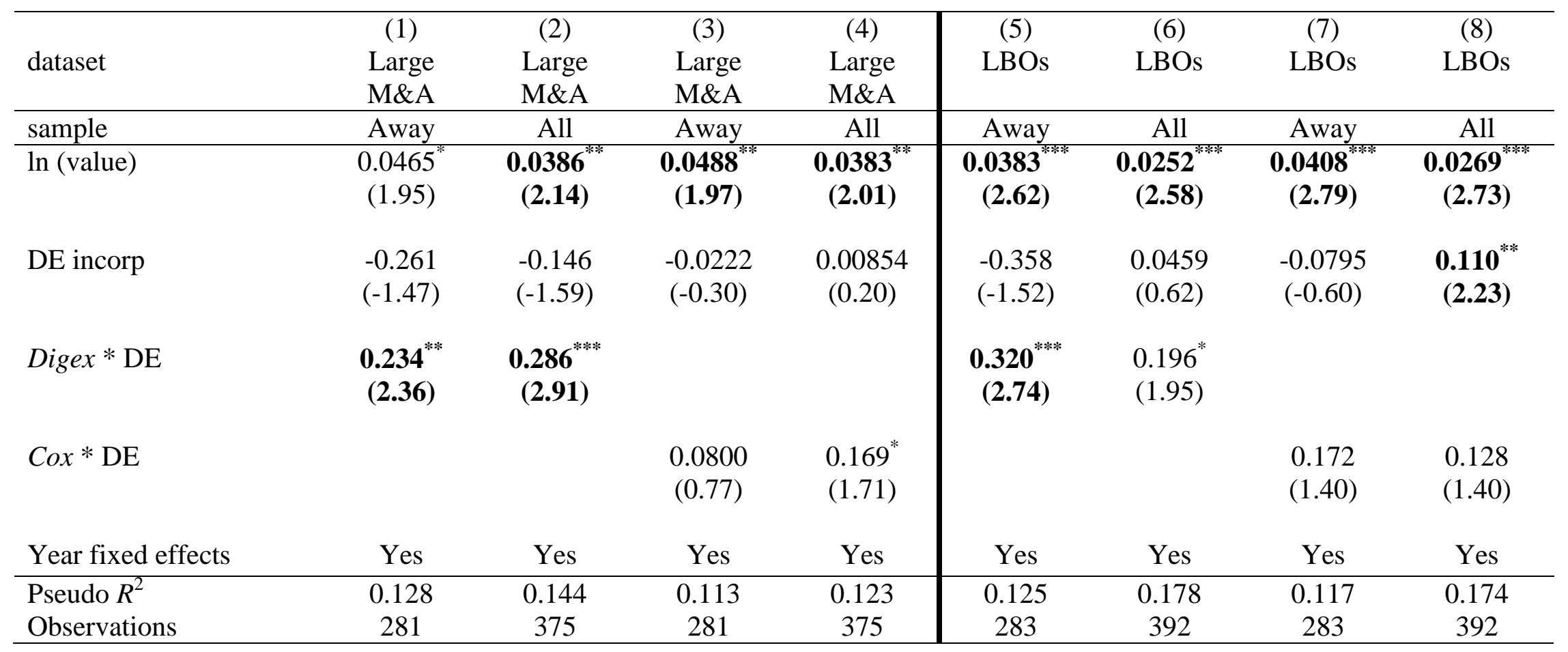

NoTE: Large M\&A sample is 25 largest M\&A transactions (mergers and tender offers) by dollar value in each year, for 1994-2010. LBO sample is leveraged buyouts over 1995-2010. Probit models, with year fixed effects, of the likelihood that a transaction attracts litigation solely outside the state of incorporation. Table shows marginal effects, holding other variables at their median values. We treat as a single consolidated suit all suits in the same jurisdiction which could have been consolidated. Digex * $\mathrm{DE}$ is a dummy variable taking the value 1 for all deals involving Delaware targets announced after the Digex fee decision on April 6, 2001, and 0 otherwise. Cox $*$ DE is a dummy variable taking the value 1 for all deals involving Delaware targets announced after the opinion in In Re Cox Communications on June 6, 2005, and 0 otherwise.

Heteroskedasticity consistent $t$ statistics are parentheses. Significant results in boldface. ${ }^{*} p<0.1,{ }^{* * *} p<0.05,{ }^{* * *} p<0.01$ 
Table 9. Days to file suit for takeover cases with suit outside Delaware

\begin{tabular}{|c|c|c|c|c|}
\hline dataset & $\begin{array}{c}(1) \\
\text { Large } \\
\text { M\&A }\end{array}$ & $\begin{array}{c}(2) \\
\text { Large } \\
\text { M\&A }\end{array}$ & $\begin{array}{c}(3) \\
\text { LBOs }\end{array}$ & $\begin{array}{c}(4) \\
\text { LBOs }\end{array}$ \\
\hline sample & Away & All & Away & All \\
\hline $\ln$ (value) & $\begin{array}{l}5.536 \\
(0.94)\end{array}$ & $\begin{array}{l}-1.454 \\
(-0.33)\end{array}$ & $\begin{array}{l}-2.487 \\
(-1.55)\end{array}$ & $\begin{array}{l}-2.349^{*} \\
(-1.75)\end{array}$ \\
\hline DE incorp & $\begin{array}{l}27.76 \\
(1.30)\end{array}$ & $\begin{array}{l}27.58^{*} \\
(1.68)\end{array}$ & $\begin{array}{l}2.930 \\
(0.21)\end{array}$ & $\begin{array}{l}-0.321 \\
(-0.03)\end{array}$ \\
\hline$T C W * \mathrm{DE}$ & $\begin{array}{c}-76.54^{* * * *} \\
(-3.02)\end{array}$ & $\begin{array}{c}-48.30 \\
(-2.63)\end{array}$ & $\begin{array}{l}1.856 \\
(0.12)\end{array}$ & $\begin{array}{l}-0.973 \\
(-0.08)\end{array}$ \\
\hline Constant & $\begin{array}{l}6.901 \\
(0.13)\end{array}$ & $\begin{array}{l}39.09 \\
(0.98)\end{array}$ & $\begin{array}{c}26.88^{* *} \\
(2.11)\end{array}$ & $\begin{array}{c}32.42^{\text {**** }} \\
(3.15)\end{array}$ \\
\hline Year fixed effects & YES & YES & YES & YES \\
\hline $\begin{array}{l}\text { Adjusted } R^{2} \\
\text { Observations }\end{array}$ & $\begin{array}{c}0.059 \\
158\end{array}$ & $\begin{array}{c}0.022 \\
219\end{array}$ & $\begin{array}{c}0.036 \\
125\end{array}$ & $\begin{array}{c}-0.012 \\
170\end{array}$ \\
\hline
\end{tabular}

NotE: Sample is suits outside Delaware, for transactions within large M\&A or LBO datasets. Large M\&A sample is 25 largest M\&A transactions (mergers and tender offers) by dollar value in each year, for 1994-2010. LBO sample is leveraged buyouts over 1995-2010. OLS regressions, with year fixed effects, of determinants of number of days between deal announcement and suit being filed. TCW $*$ DE is a dummy variable that equals 1 for deals involving Delaware targets announced after the TCW Technology decision on October 17, 2000, and 0 otherwise. Heteroskedasticity consistent $t$ statistics are parentheses. Significant results in boldface. ${ }^{*} p<0.1,{ }^{* * *} p<0.05,{ }^{* * *} p<$ 0.01 . 
Figure 1: Summary of datasets

(3)

\begin{tabular}{|c|c|c|c|c|}
\hline Dataset & $\begin{array}{l}\text { Large M\&A } \\
\text { Transactions }\end{array}$ & $\begin{array}{l}\text { Leveraged } \\
\text { Buyouts }\end{array}$ & $\begin{array}{l}\text { Cases leading to } \\
\text { judicial opinions }\end{array}$ & $\begin{array}{c}\text { Options } \\
\text { backdating suits }\end{array}$ \\
\hline Search strategy & $\begin{array}{l}\text { SEC filings- } \\
\text { look for } \\
\text { disclosure of suit }\end{array}$ & $\begin{array}{l}\text { SEC filings- } \\
\text { look for } \\
\text { disclosure of suit }\end{array}$ & $\begin{array}{l}\text { Lexis, Westlaw, } \\
\text { court websites }\end{array}$ & $\begin{array}{l}\text { Plaintiff law } \\
\text { firms and insurer } \\
\text { case lists }\end{array}$ \\
\hline Time period & 1994-2010 & 1994-2010 & 1995-2009 & 2006-2010 \\
\hline $\begin{array}{l}\text { Comparative } \\
\text { advantages }\end{array}$ & $\begin{array}{l}\text { Time series } \\
\text { analysis of filing }\end{array}$ & $\begin{array}{l}\text { Time series } \\
\text { analysis of filings }\end{array}$ & $\begin{array}{l}\text { precedent } \\
\text { generating cases }\end{array}$ & $\begin{array}{l}\text { Derivative suits } \\
\text { Often good cases }\end{array}$ \\
\hline & & $\begin{array}{l}\text { Conflict of } \\
\text { interest } \\
\text { transactions, } \\
\text { likely to be good } \\
\text { cases on average }\end{array}$ & $\begin{array}{l}\text { both direct and } \\
\text { derivative cases }\end{array}$ & $\begin{array}{l}\text { Settlement } \\
\text { outcomes } \\
\text { available } \\
\text { Information on } \\
\text { stay motions }\end{array}$ \\
\hline Limitations & $\begin{array}{l}\text { Only direct, } \\
\text { mostly class } \\
\text { action suits. } \\
\text { No data on } \\
\text { outcomes } \\
\text { Many suits have } \\
\text { limited merit, low } \\
\text { or zero dollar } \\
\text { recovery }\end{array}$ & $\begin{array}{l}\text { Only direct, } \\
\text { mostly class } \\
\text { action suits. } \\
\text { No data on } \\
\text { outcomes }\end{array}$ & $\begin{array}{l}\text { Sample selection } \\
\text { bias: many } \\
\text { cases don't lead } \\
\text { to opinions } \\
\text { No data on } \\
\text { outcomes }\end{array}$ & $\begin{array}{l}\text { Only derivative } \\
\text { suits } \\
\text { No time series } \\
\text { (most suits } \\
\text { initially brought } \\
\text { in 2006-2007 }\end{array}$ \\
\hline
\end{tabular}


Figure 2: Rate and location of suits against Delaware target companies in large M\&A transactions

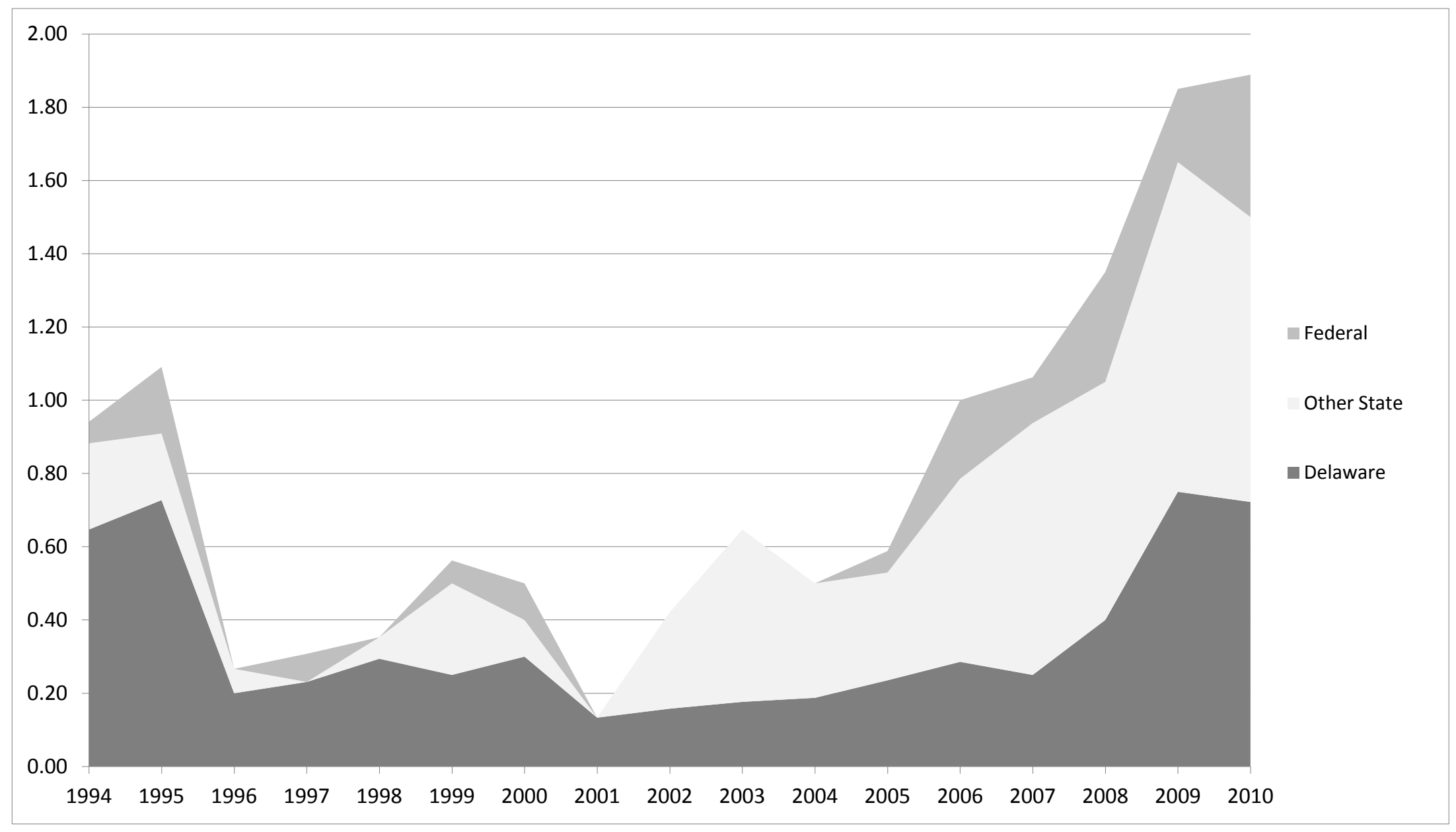

NOTE: Sample is transactions within 25 largest M\&A transactions (mergers and tender offers) by dollar value in each year, for 1994-2010 that involve Delaware targets.

Figure shows annual ratio and location (Delaware, other state court, or federal court) of suits under corporate law challenging these transactions. We treat as a single

consolidated suit all suits in the same jurisdiction which could have been consolidated. Annual number of transactions with Delaware targets varies from 11 to 20 , see Table 1 , Panel A for details. 
Figure 3. Location of suits against Delaware target companies in large M\&A transactions: proportions

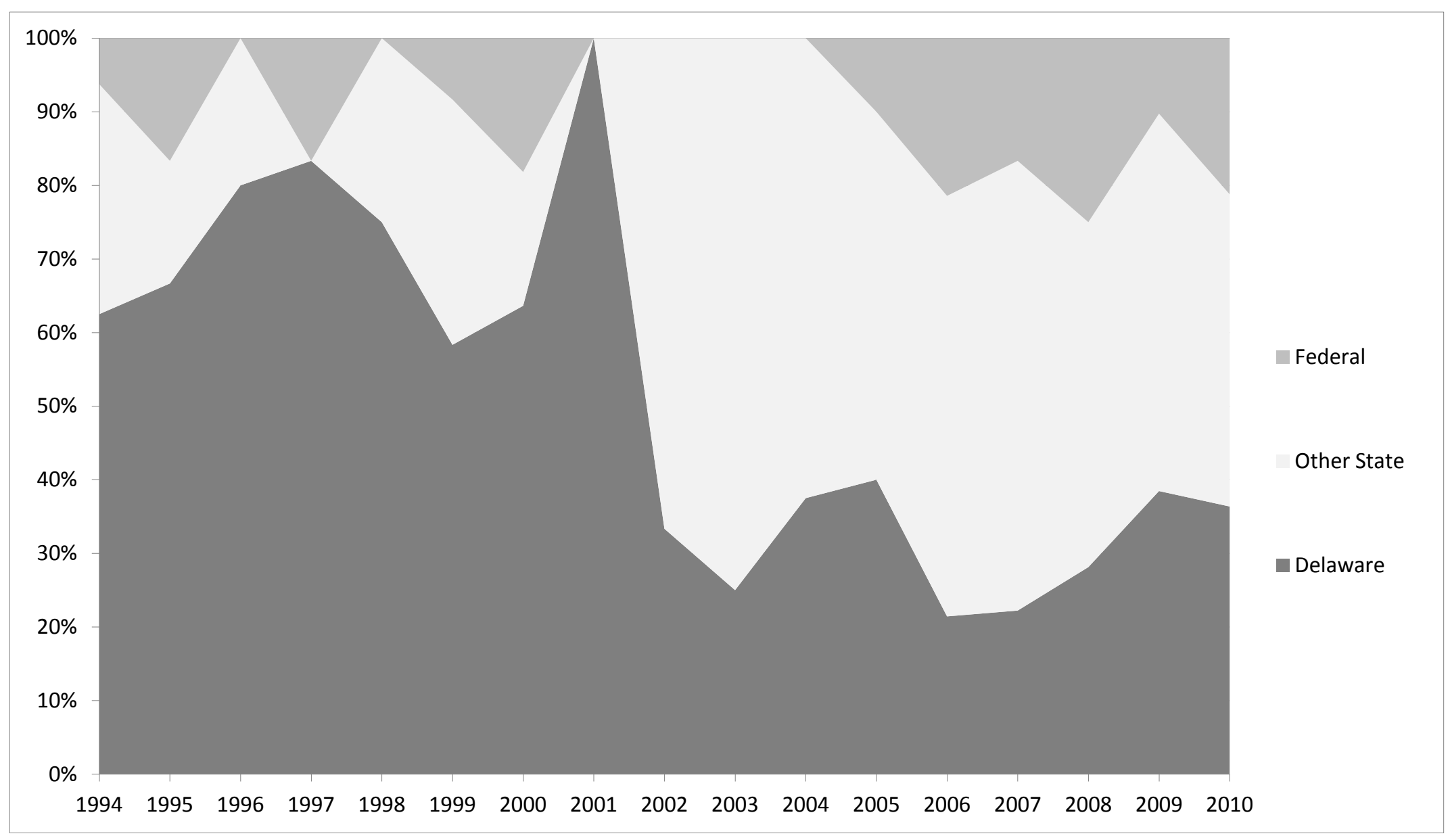

NOTE: Sample is transactions, within 25 largest M\&A transactions (mergers and tender offers) by dollar value in each year for 1994-2010, that involve Delaware targets and attract one or more lawsuits under corporate law. Figure shows proportion of suits in each location (Delaware, other state court, or federal court) challenging these transactions. We treat as a single consolidated suit all suits in the same jurisdiction which could have been consolidated. Annual sample size varies from 2 to 17. 
Figure 4: Proportion of large M\&A deals generating litigation

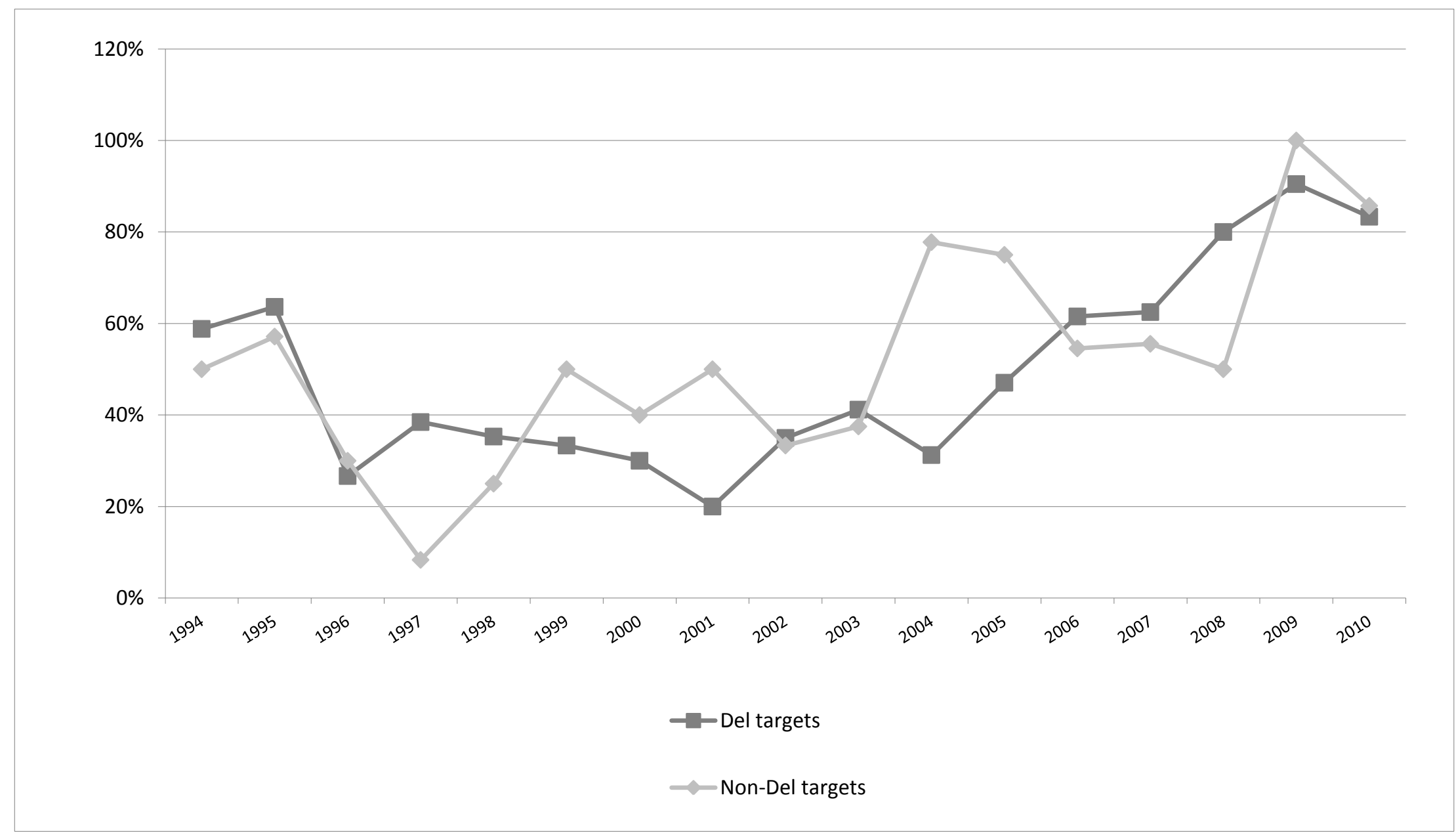

NOTE: Sample is 25 largest M\&A transactions (mergers and tender offers) by dollar value in each year, for 1994-2010. Graph indicates, separately for Delaware and nonDelaware targets, the likelihood that a transaction will attract one or more suits. 
Figure 5: Proportion of large M\&A transactions attracting more than one suit.

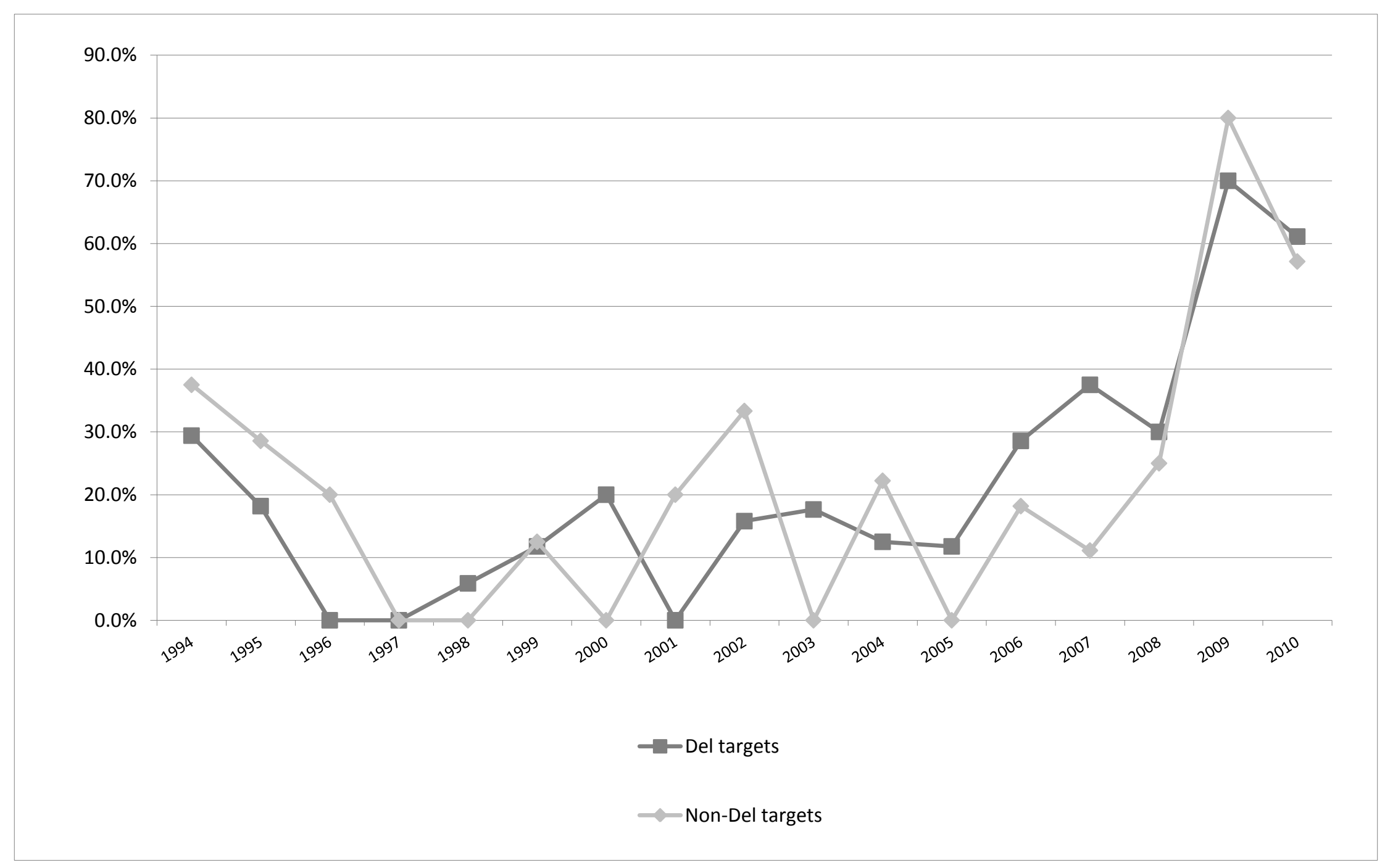

NOTE: Sample is 25 largest M\&A transactions (mergers and tender offers) by dollar value in each year, for 1994-2010. Graph indicates, separately for Delaware and nonDelaware targets, the likelihood that a transaction will attract more than one consolidated lawsuit under corporate law. We treat as consolidated all suits which could be consolidated. 
Figure 6: Litigation patterns for large M\&A transactions involving Delaware targets with lawsuits

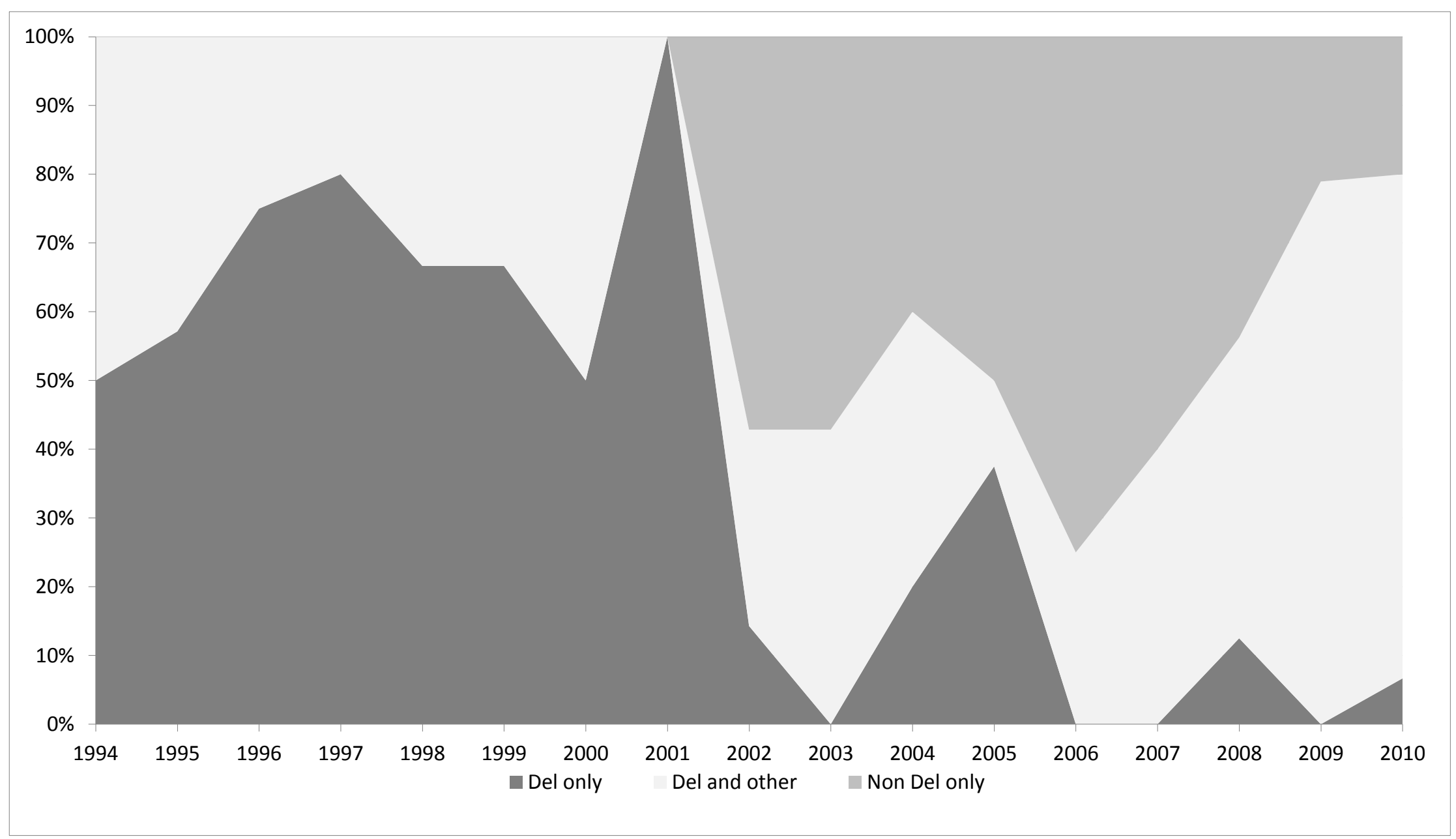

NOTE: Sample is transactions, within 25 largest M\&A transactions (mergers and tender offers) by dollar value in each year for 1994-2010, which involve Delaware targets and attract one or more suits under corporate law. Bottom area indicates proportion of these transactions with suit only in Delaware state courts. Middle area indicates proportion with suits both in Delaware state courts and elsewhere; top portion indicates proportion with suit(s) filed only outside Delaware state courts. 
Figure 7: Rate and location of suits for leveraged buyouts of Delaware companies

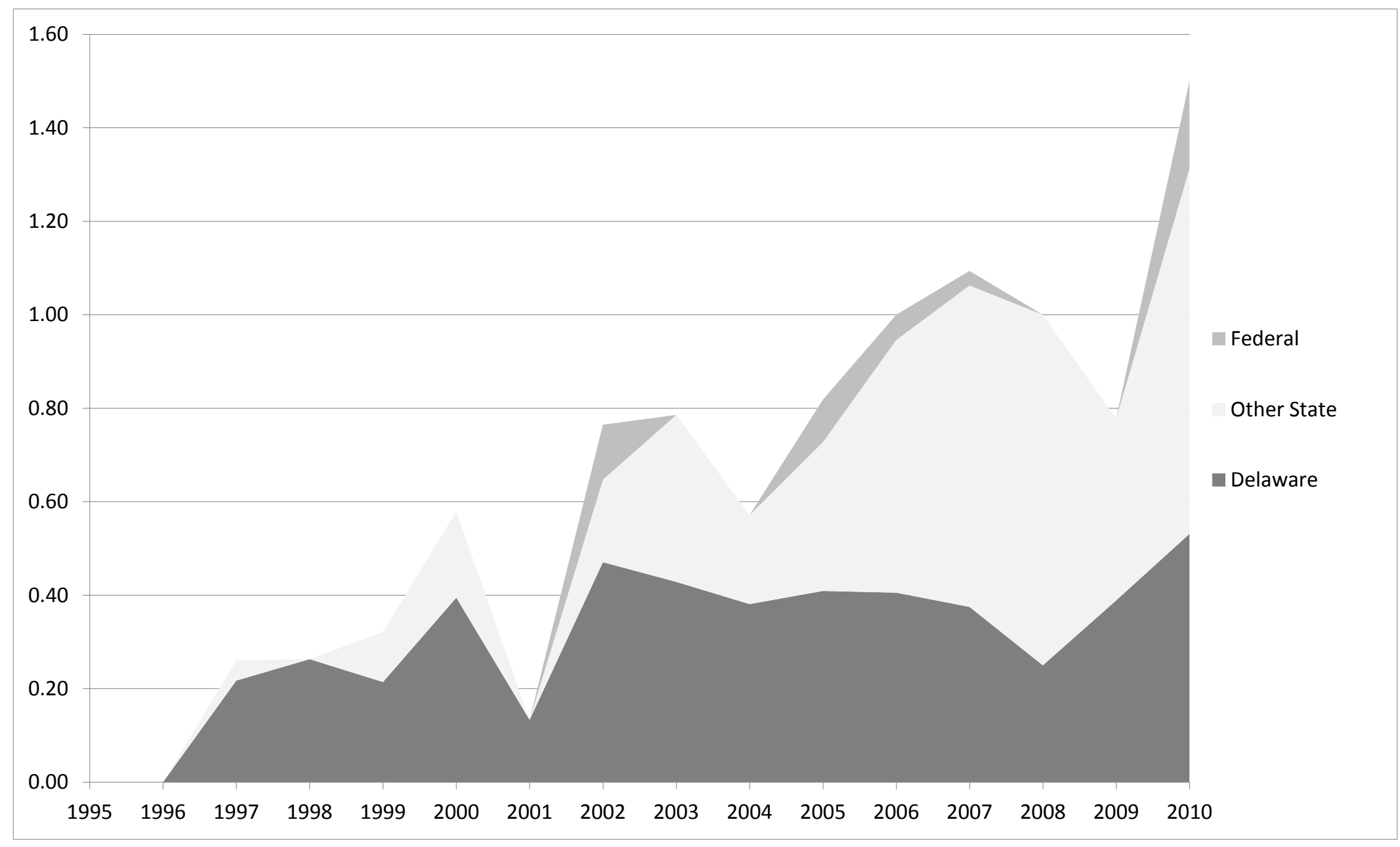

NOTE: Sample is leveraged buyouts over 1995-2010 that involve Delaware targets. Figure shows annual ratio and location (Delaware, other state court, or federal court) of suits under corporate law challenging these transactions. Annual sample size varies from 4 to 38 ; see Table 1, Panel B for details. We treat as a single consolidated suit all suits in the same jurisdiction which could have been consolidated. 
Figure 8. Location of suits for leveraged buyouts of Delaware companies: proportions

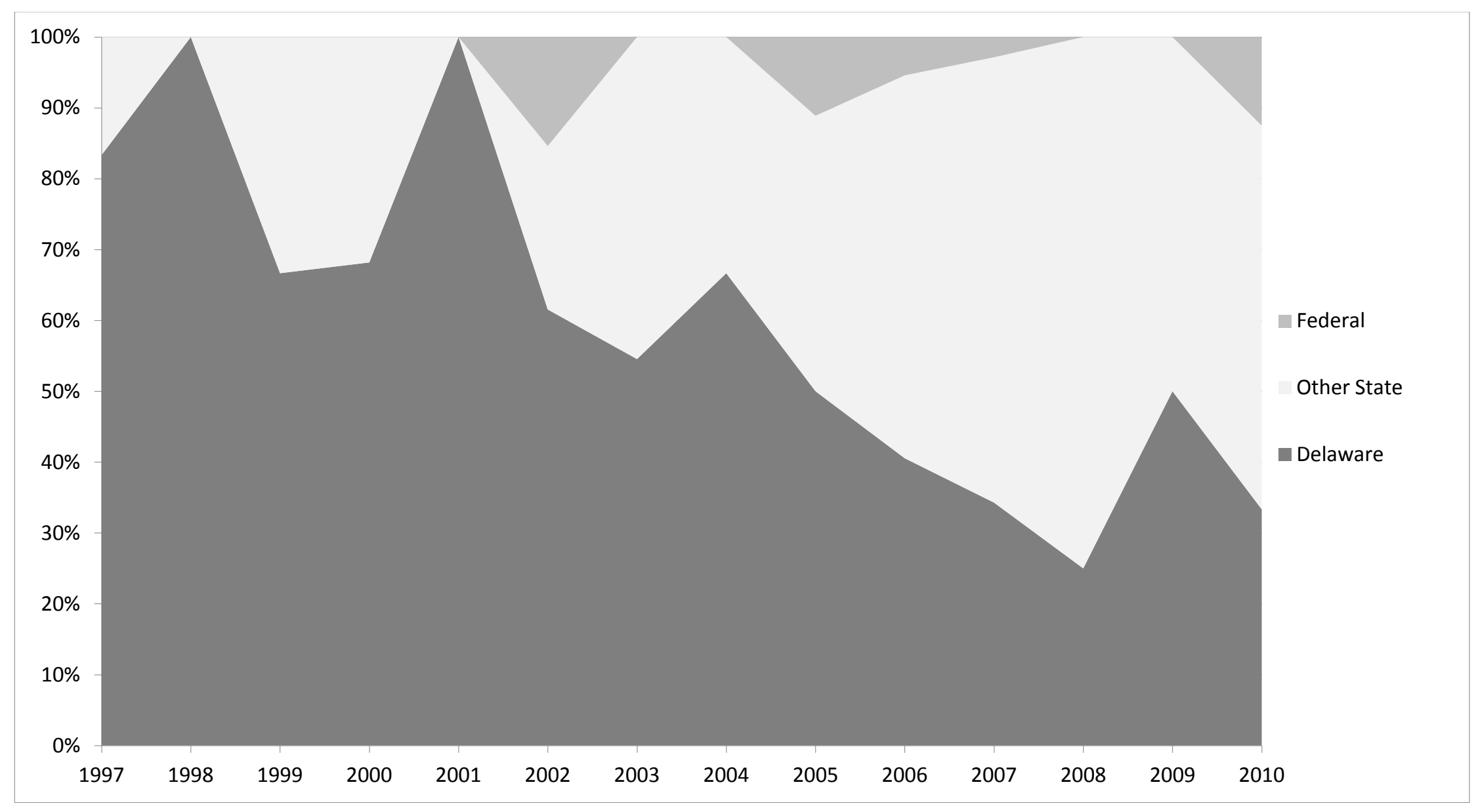

NOTE: Sample is Leveraged buyouts over 1997-2010 that involve Delaware targets and attract one or more suits under corporate law. There were no lawsuits in 1995-1996. Figure shows proportion of suits in each location (Delaware, other state court, or federal court). Annual sample size varies from 2 to 22 . We treat as a single consolidated suit all suits in the same jurisdiction which could have been consolidated. 
Figure 9: Proportion of leveraged buyouts generating litigation

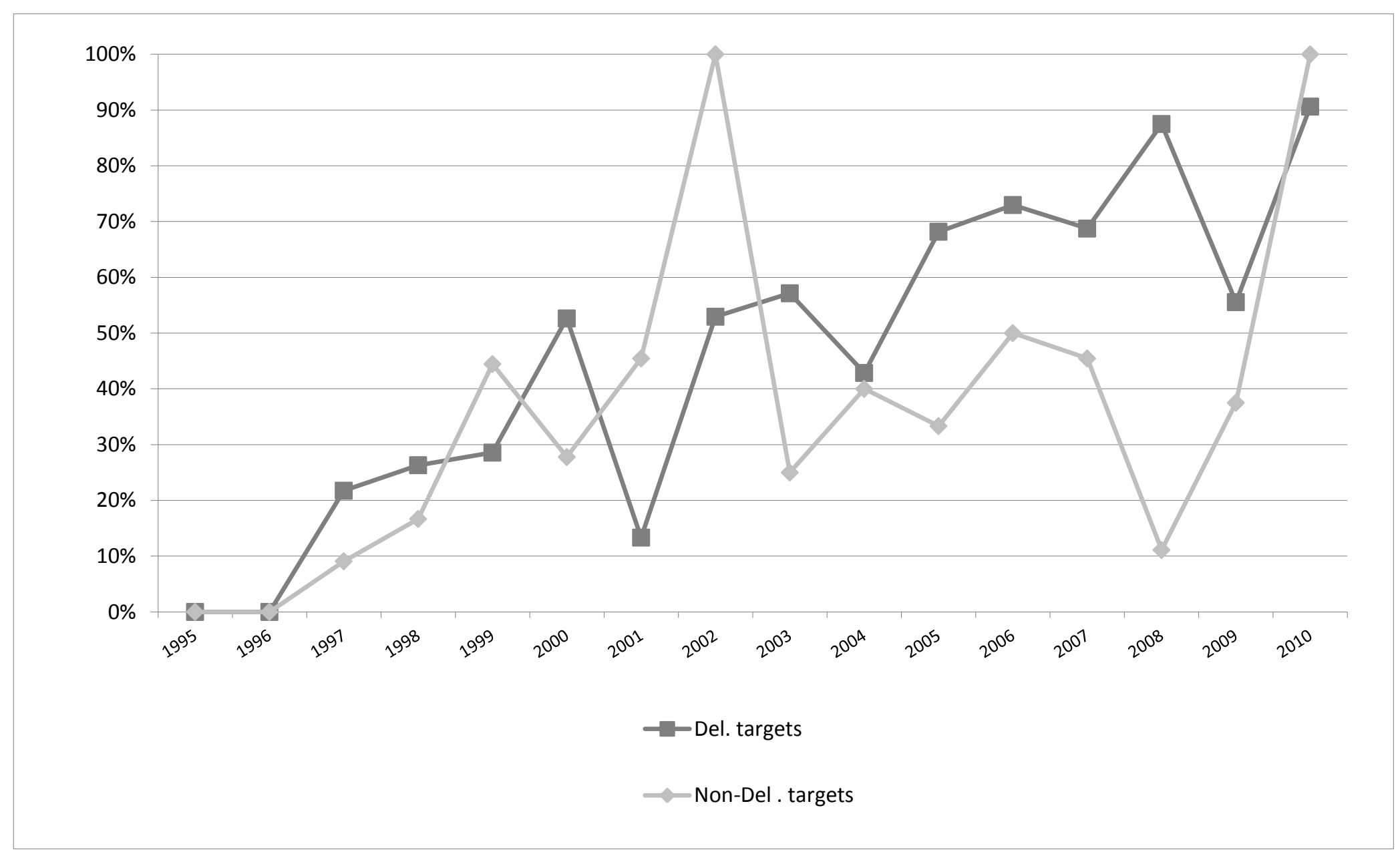

NOTE: Sample is leveraged buyouts over 1995-2010. Graph indicates, separately for Delaware and non-Delaware targets, the likelihood that a transaction will attract one or more suits under corporate law. 
Figure 10: Proportion of leveraged buyouts attracting more than one suit.

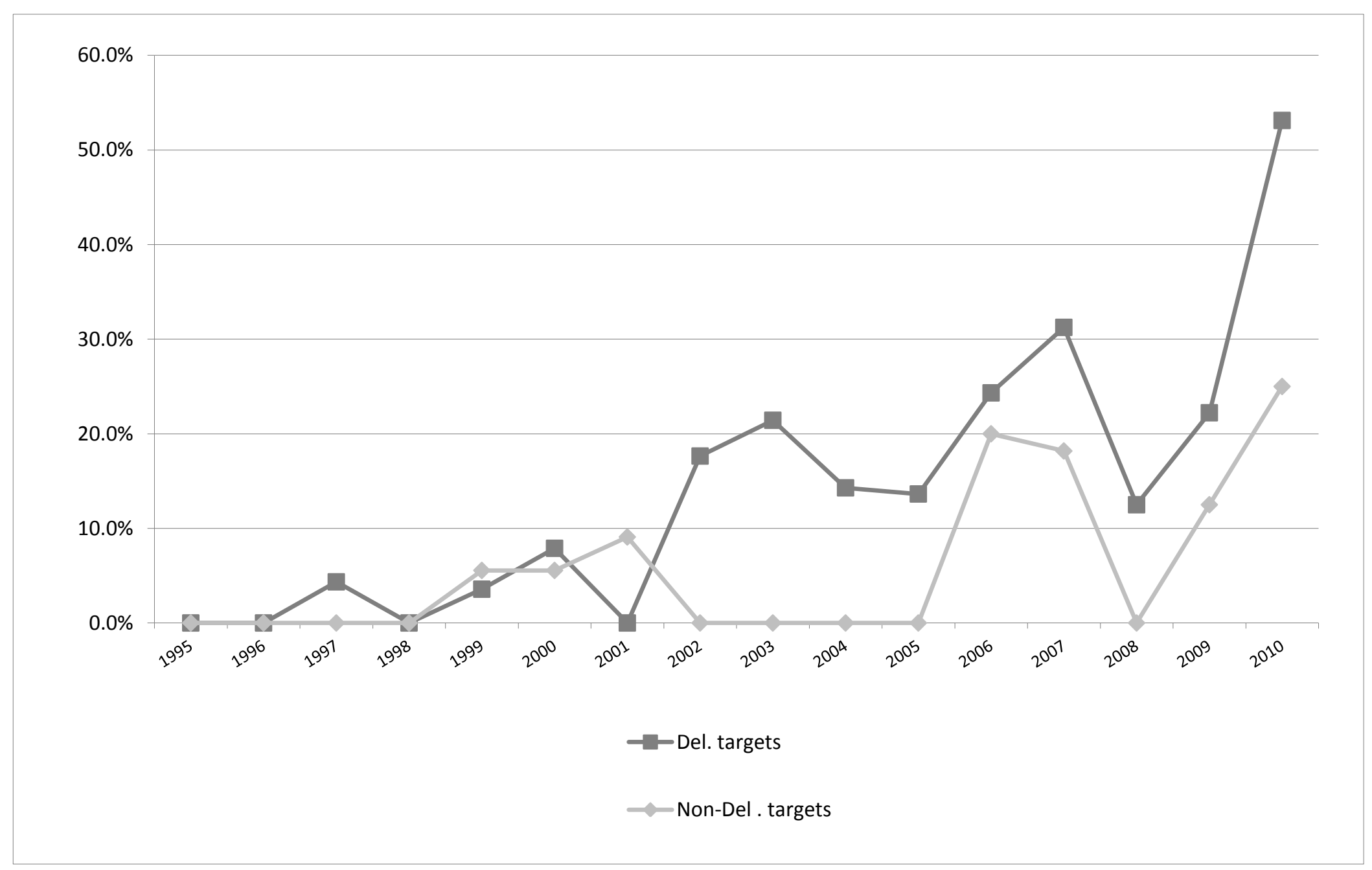

NOTE: Sample is leveraged buyouts over 1995-2010. Graph indicates, separately for Delaware and non-Delaware targets, the likelihood that a buyout will attract more than one consolidated lawsuit under corporate law. We treat as consolidated all suits which could be consolidated. Since there are no bidder suits in the LBO dataset, the incidence of more than one consolidated lawsuit is that of multi-forum litigation. 
Figure 11: Litigation patterns for leveraged buyouts involving Delaware targets with lawsuits

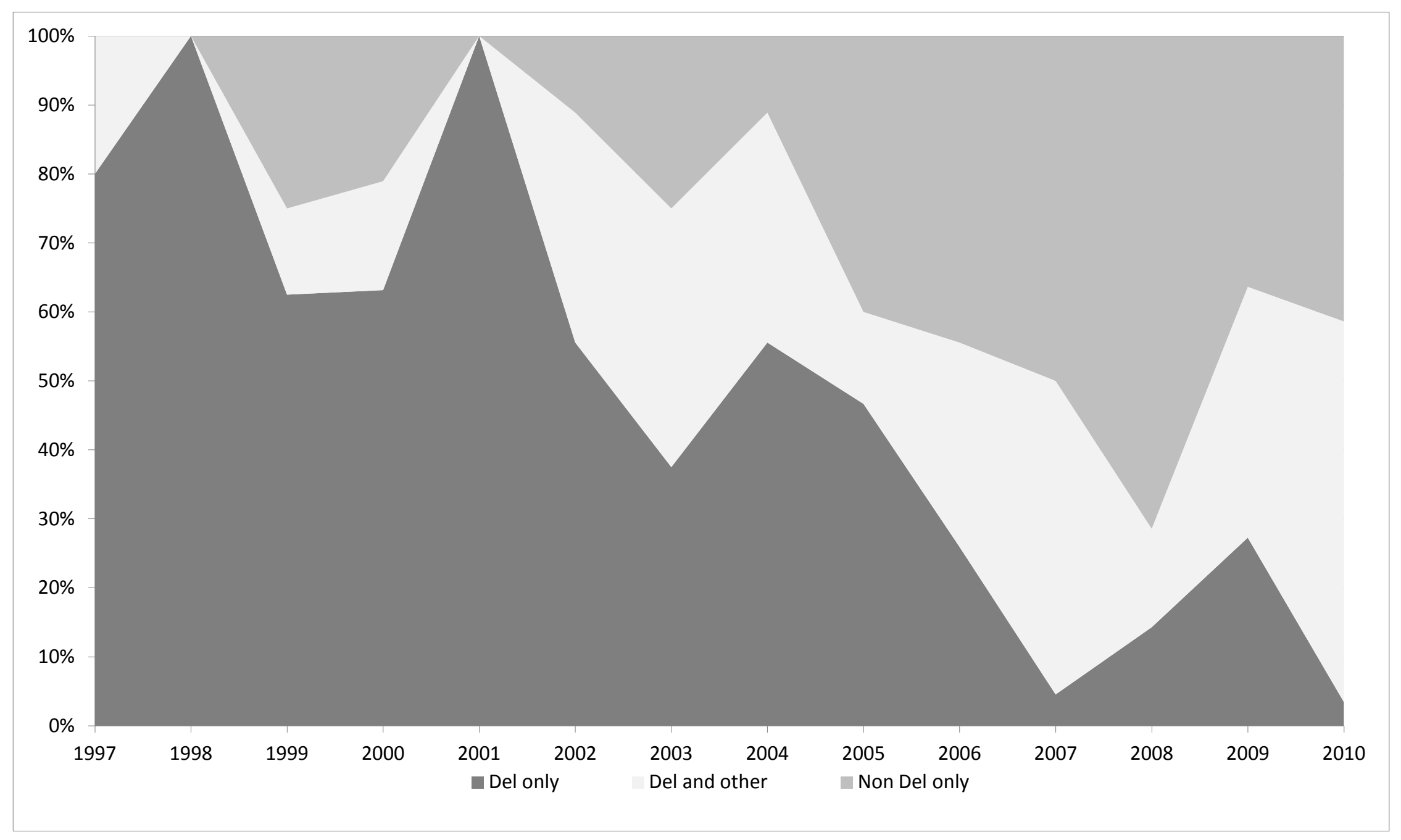

NOTE: Sample is leveraged buyouts of Delaware companies that attract one or more lawsuits under corporate law, over 1997-2010. There were no lawsuits in 1995-1996. Bottom area indicates proportion of these transactions with suit only in Delaware. Middle area indicates proportion with suit both in Delaware and elsewhere; top portion indicates proportion with suit filed only outside Delaware. 
Figure 12: Suits against directors generating judicial opinions

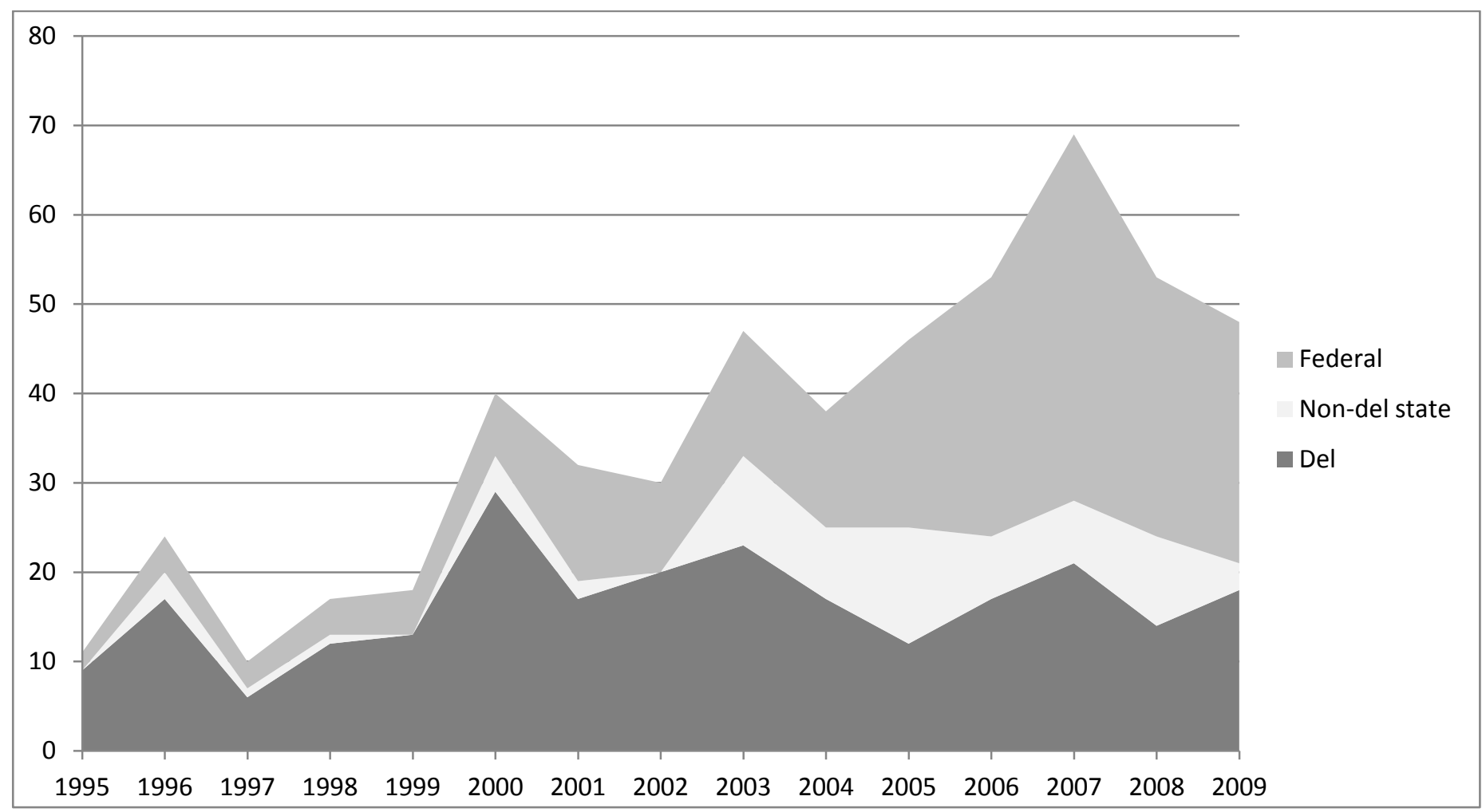

NOTE: Number and location (Delaware, other state court, or federal court) of suits against directors of Delaware public companies leading to one or more judicial opinions, with first opinion from 1995-2009. 
Figure 13: Location of suits against directors generating judicial opinions: proportions

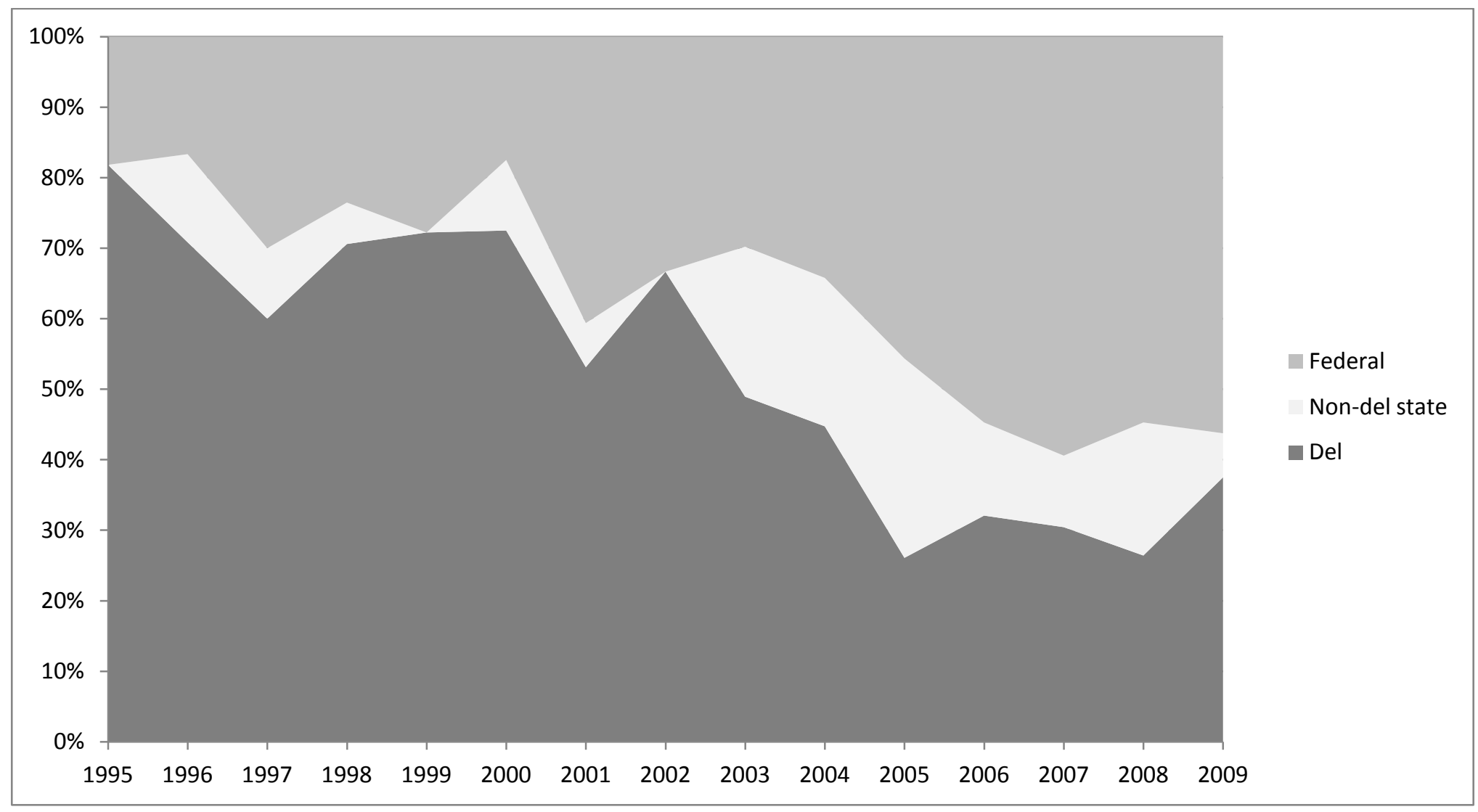

NOTE: Proportion of suits in each location (Delaware, other state court, or federal court) for suits against directors of Delaware public companies leading to one or more judicial opinions, with first opinion from 1995-2009. 
Figure 14: Location of suits against directors generating judicial opinions: normalized proportions

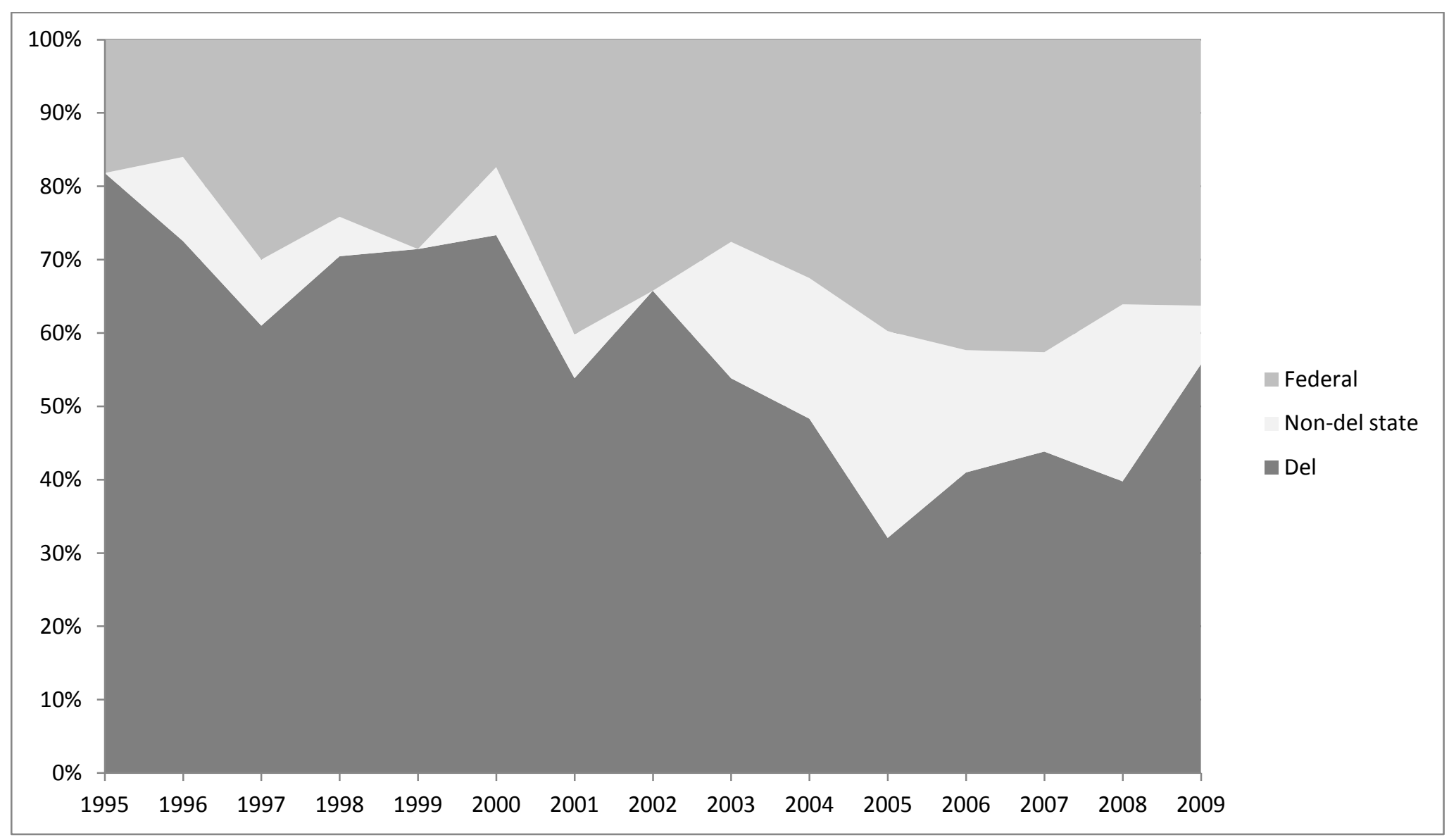

NOTE: Proportion of suits in each location (Delaware, other state court, or federal court) for suits against directors of Delaware public companies leading to one or more judicial opinions, with first opinion from 1995-2009. Annual totals have been normalized according to ratio of total number of opinions of that type reported in Westlaw for that year relative to a benchmark of 1995 . 